\title{
Save water or save wildlife? Water use and conservation in the central Sierran foothill oak woodlands of California, USA
}

\author{
$\underline{\text { Lynn Huntsinger }}^{1}, \underline{\text { Tracy V. Hruska }}^{1}, \underline{\text { Jose L. Oviedo }}^{2}, \underline{\text { Matthew W. K. Shapero }}^{1}, \underline{\text { Glenn A. Nader }}^{3}, \underline{\text { Roger S. Ingram }}^{3}$ and Steven R. $^{\text {Ste }}$ \\ Beissinger $^{1}$
}

\begin{abstract}
More frequent drought is projected for California. As water supplies constrict, and urban growth and out-migration spread to rural areas, trade-offs in water use for agriculture, biodiversity conservation, fire hazard reduction, residential development, and quality of life will be exacerbated. The California Black Rail (Laterallus jamaicensis coturniculus), state listed as "Threatened," depends on leaks from antiquated irrigation district irrigation systems for much of its remnant small wetland habitat in the north central Sierra Nevada foothills. Residents of the $1295 \mathrm{~km}^{2}$ foothill habitat distribution of the Black Rail were surveyed about water use. Results show that the most Black Rail habitat is owned by those purchasing water to irrigate pasture, a use that commonly creates wetlands from leaks and tailwater. Promoting wildlife, agricultural production, and preventing wildfire are common resident goals that call for abundant and inexpensive water; social and economic pressures encourage reduction in water use and the repair of leaks that benefit wildlife and greenery. Broad inflexible state interventions to curtail water use are likely to create a multitude of unintended consequences, including loss of biodiversity and environmental quality, and alienation of residents as valued ecosystem services literally dry up. Adaptive and proactive policies are needed that consider the linkages in the social-ecological system, are sensitive to local conditions, prevent landscape dewatering, and recognize the beneficial use of water to support ecosystem services such as wildlife habitat. Much Black Rail habitat is anthropogenic, created at the nexus of local governance, plentiful water, agricultural practices, historical events, and changing land uses. This history should be recognized and leveraged rather than ignored in a rush to "save" water by unraveling the social-ecological system that created the landscape. Policy and governance needs to identify and prioritize habitat areas to maintain during drought.
\end{abstract}

Key Words: agroforestry; conservation trade-offs; ecosystem services; endangered species; irrigation; social-ecological systems; water systems; wetlands

\section{INTRODUCTION}

On 17 January 2015, in the midst of California's fourth consecutive dry winter, Governor Jerry Brown declared a drought state of emergency and asked everyone in the state to voluntarily reduce water use by $20 \%$ (State of California 2014). California's 2014 and 2015 water years, which ended 30 September 2015, were the warmest years in 119 years of record keeping (USGS 2015). On 1 April 2015, the Governor issued an Executive Order that, for the first time in state history, required the State Water Resource Control Board (SWRCB) to enforce a $25 \%$ reduction in water use for cities and towns (State of California 2015). Unfortunately, this unprecedented drought is probably a harbinger of things to come because climate change is likely to increase the frequency and severity of drought in the future (Polade et al. 2014, Byrd et al. 2015). In the foothill communities of the Sierra Nevada, the immediate impacts of the four-year drought included water thefts, early livestock sales, and yet another deadly and expensive wildfire season. In the long term, valuable ecosystem services, including wetland bird habitats, are at risk of loss because of the interaction of water policy and the social-ecological system providing such services.

Summer means months without rain in most of California. In addition to numerous federal and state water projects, the state has 1286 water special districts, including the irrigation districts in the central Sierran foothills. They were formed in the late 19th and early 20th centuries by farmers and ranchers to provide summer irrigation. Each has a diverse set of histories, purposes, governance structures, and financing mechanisms (CA-LAO
2002), but all are mandated to efficiently convey water to users as a top priority. The main source of water is the snowpack of the Sierra Nevada.

Irrigation districts control much of the surface water in the foothills. Mostly they deliver nonpotable irrigation water, but there is growing demand for potable water for households, and districts increasingly supply it, using different infrastructure. Recent state restrictions on water use have so far mostly targeted nonagricultural uses, but there has been increasing political pressure from urban areas to reduce agricultural use. Though the rural irrigation districts in our study area do not serve major metropolitan areas, water not used for local agriculture may reach thirsty urban areas through water sales or runoff to major rivers, putting further pressure on rural districts to conserve.

In western agricultural landscapes, irrigation systems and wildlife are most often positioned as competing for limited water resources. However, irrigation systems can provide multiple ecosystem services, particularly in arid ecosystems. Traditional agricultural systems may enhance vegetative cover and diversity, create wildlife habitat, recharge shallow aquifers, sequester carbon, improve air and water quality, retain storm-water flow, and control flooding (Fleming et al. 2014). Habitat may be created by leakage and by "return flow," the recharging of groundwater by water used for agriculture. Water may be used more than once as it flows into the ground from irrigation high in the hills and emerges again at lower elevations in creeks, seeps, and springs (Peck and Levvorn 2001, Weiner et al. 2008, Welsh et al. 2013).

${ }^{1}$ Environmental Science, Policy, and Management, University of California, Berkeley, ${ }^{2}$ Institute of Public Goods and Policies (IPP), Consejo Superior de Investigaciones Científicas (CSIC), Madrid, ${ }^{3}$ University of California Cooperative Extension 
Studies have shown that leaks from canals and other irrigation infrastructure can provide significant water to wetlands and springs up to $2 \mathrm{~km}$ away (Sueltenfuss et al. 2013). The impacts of irrigation projects on the Colorado Front Range have been described as creating a "pond-spotted, greened-up, highlyenriched new urban-suburban peri-urban landscape" where "the human-created riparian/creekside/ditchside environments may now be more extensive than the natural riparian areas ever were" (Weiner et al. 2008:20).

In the northcentral Sierra foothills, the landscape has become similarly spotted with ponds, wetlands, and other water features. Irrigation districts often rely on leaky Gold Rush era (1849) canals and wooden flumes to bring water down from community constructed reservoirs high up in the mountains. As much as half of the water flowing through a canal may escape through its earthen floors and walls (Luckey and Cannia 2006), often to emerge in seeps and springs downhill, creating green areas and wildlife habitat. Additionally, residents use water from wells, creeks, and other sources, spreading water on the landscape for various purposes and creating wet spots.

The California Black Rail (Laterallus jamaicensis coturniculus; hereafter Black Rail), is a small, secretive wetland bird first discovered in the Sierra foothills in 1994 (Aigner et al. 1995), although genetic evidence suggests a historical presence in the region (Girard et al. 2010). This species is listed in California as "Threatened" and primarily occurs in large wetlands (typically > 100 ha) in the San Francisco Bay estuary (Richmond et al. 2008). In the Sierra foothills, however, the Black Rail mostly inhabits small wetlands (median $=0.67 \mathrm{ha}$ ) along a midelevational strip of oak woodlands and grasslands in Yuba and Nevada counties (Fig. 1). The Black Rail depends on small wetlands, preferring grassy areas with perennial shallow flowing water (Fig. 2). Wetlands most frequently occupied by Black Rails are found on properties that have irrigation infrastructure, specifically pipes, canals, and irrigated pasture (Richmond et al. 2008, 2010). The anthropogenic wetlands are also used by other water-dependent species of plants and animals. They dry out when a leaky pipe is fixed, or an earthen canal is lined with cement or converted to pipe.

Climate and land use change, drought, and increased competition for water mean that new and changing policies for water conservation are likely in the near future. As water supplies constrict, trade-offs will arise in water use for agriculture, wildlife and natural vegetation, diverse land uses, fire hazard reduction, and even quality of life. In this context, understanding landowner water use and decision making will help anticipate the impact of changes in water availability and how they will feed back to foothill habitat (Welsh et al. 2013).

We report results of a mail survey exploring the potential consequences of water conservation policy on water use and ecosystem services. Landowners and managers of properties within the Sierran foothills distribution of the Black Rail were surveyed to understand their attitudes toward water resource policy, education, and management, and to anticipate the likely impacts of change to the social-ecological system that provides habitat for the Black Rail. In addition to standard demographic questions, respondents were asked about their water sources and uses, and what they would do if water availability or price changed.
Fig. 1. The foothill habitat distribution of the California Black Rail (Laterallus jamaicensis coturniculus) is the study area. Although most respondents purchased water from one of the two main irrigation districts serving the study area, 11 different districts were used.

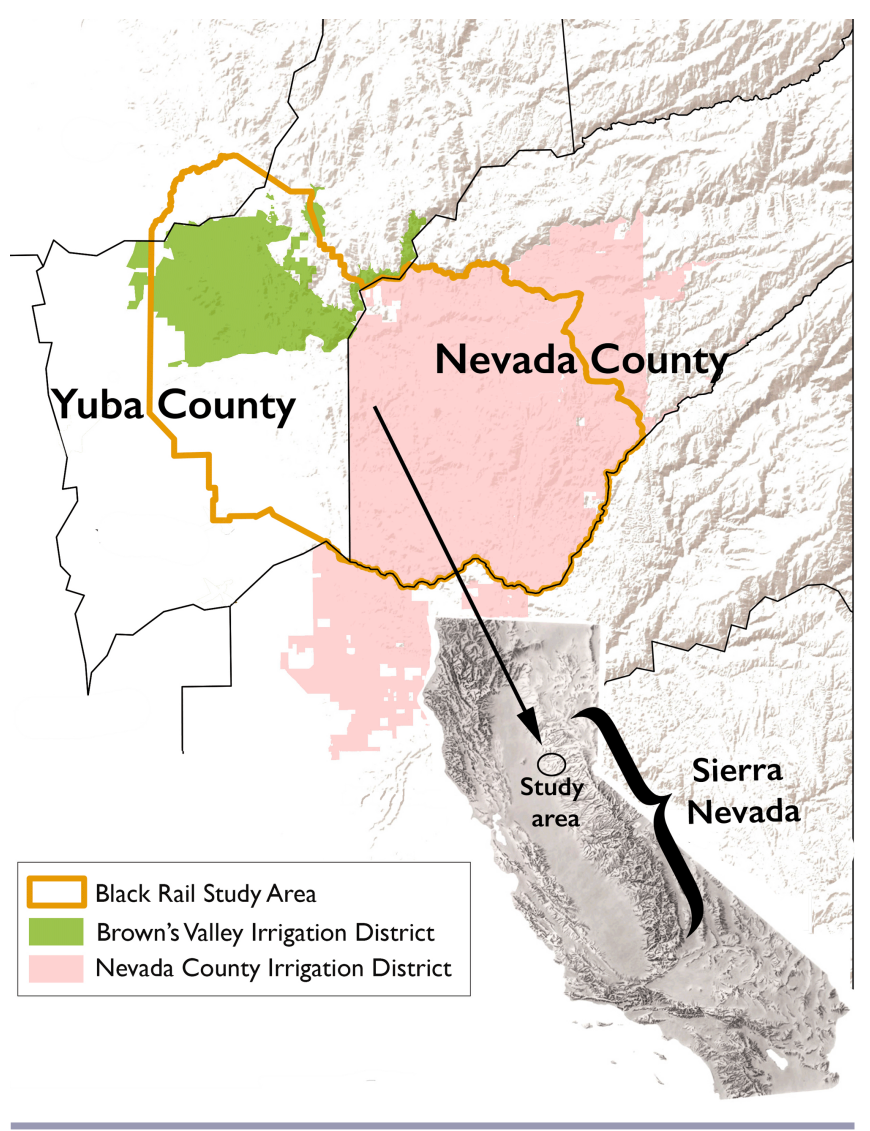

Fig. 2. Shallow wetlands caused by runoff and leaks from pastures, pipes, or canals. In these habitats, the water is flowing and not static and may feed pastures, springs, and wetlands lower down.

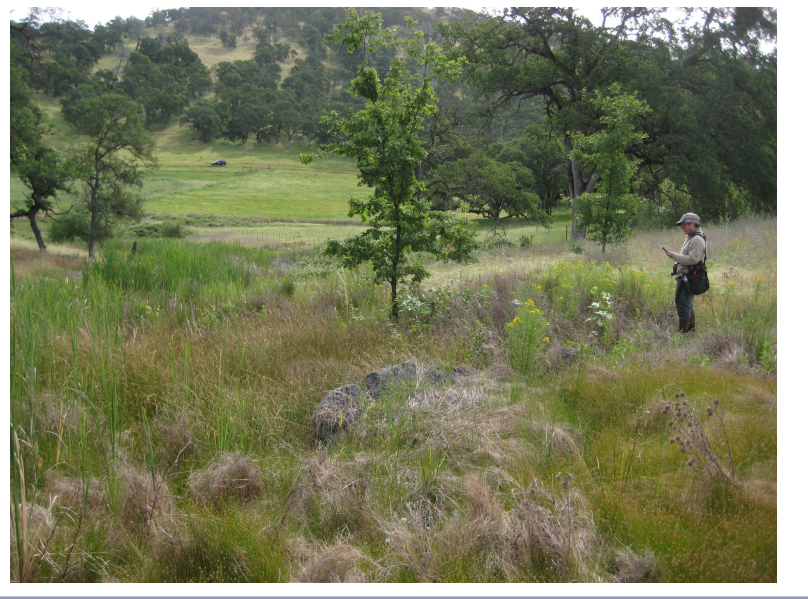




\section{STUDY AREA}

The study area is the $1295 \mathrm{~km}^{2}$ known distribution of the Black Rail in the Sierra Nevada foothills (Richmond et al. 2008, 2010). The area ranges in elevation from 15 to 936 meters above sea level. Black Rail habitat is located in the rolling oak woodlands stretching north to south below the forests of the Sierra's higher elevations and above the floodplain of California's Central Valley below (Fig. 1). The area has a Mediterranean climate, with hot, dry summers and cool, wet winters, and an average annual precipitation of approximately $60 \mathrm{~cm}, 90 \%$ of which falls between October and March (Lewis et al. 2000). Much of the water for the state's agriculture and nearly 39 million residents flows through the foothills, both above and below ground (O'Geen et al. 2010). Frequent droughts and the summer dry periods result in high wildfire risk, especially in brushy or wooded areas.

Because of the varied terrain, lack of summer rain, and mostly rocky and shallow soils, extensive livestock ranching emerged historically as the most viable form of agriculture. Many ranchers have come to rely on irrigated pastures and stockponds to supplement the summe's dry, annual grasslands.

The logging and grazing economies that were once predominant have been overshadowed in recent decades by increasing residential and urban development, including low-density sprawl that radiates out of small urban centers like Marysville, Grass Valley, and Nevada City, and largely consists of homes for retirees and telecommuters from Sacramento and the San Francisco Bay Area (Walker et al. 2003). The central Sierran foothills have frequently been described as an epicenter of urban out-migration and expansion in California (US EPA 2009, CAL FIRE 2010), reducing and altering habitat for Black Rail and other native wildlife. Popular are "ranchettes" or homes on a hectare or more where people can keep horses or small stock, or simply enjoy the amenities of a rural lifestyle. Some wine grape production has worked its way into the hills in the last decade or so. The mix of older production-oriented land uses with recent urban flight and telecommuting has led to a diversity of goals, sources of economic support, and land uses within foothill communities. Water uses have also changed and diversified.

Most of the study area is serviced by hundreds of miles of irrigation infrastructure belonging to two irrigation districts: the Nevada Irrigation District (NID) and the Browns Valley Irrigation District (BVID; Fig. 1). They deliver mostly raw (untreated and nonpotable) water as a diversion of flow from the district canal or pipe (Fig. 3). A water purchaser pays for water based on flow rate. The flow rate is determined by the size of the (adjustable) aperture; a larger aperture, which allows a larger flow of water, costs more than a small aperture. Flow is purchased for the full length of the irrigation season (April to October) and fees are not dependent on the amount of water actually used. If the water purchaser closes the outlet from the canal or pipeline, the water bypasses the property. If water flow is reduced at the top of the canal, or if residents earlier in the canal use more water than usual, those at the lower reaches may not get their expected flow. In both cases, the fee for the season does not change.

A few larger properties continue to purchase water that was allocated when the irrigation districts were established around the turn of the 20th century, but the vast majority of accounts were started in recent decades. During the drought of 1976-1977, BVID had roughly 30 customers. Now, less than 40 years later, the District's customer base has ballooned to over 1500 . The ability of NID and BVID to deliver water is limited by the amount of water that can physically flow through the ditches; as a result, there is a waiting list for new irrigation water allocations.

Historically, customers who reduced or stopped the purchase of irrigation water often lost their water allocation, as the allocation was shifted to those on the waiting list. Under California Water Code Section 1240, water users are required to put the water to "beneficial use" to maintain their allocation. Beneficial use may include agricultural, environmental, industrial, or residential uses as defined in a particular water right. The specifics vary by location and situation, and thus the definition of beneficial use remains to some degree open to interpretation. Landowners in general are well aware that irrigation water increases real estate values, and want to show that they are using their water.

Fig. 3. Water delivery canal. Canals that have not been piped or lined with cement create areas of green riparian vegetation that persists through the dry summers. Water leaking through the earthen floors and walls may provide "return flow," recharging aquifers and emerging lower in the hills in seeps and springs.

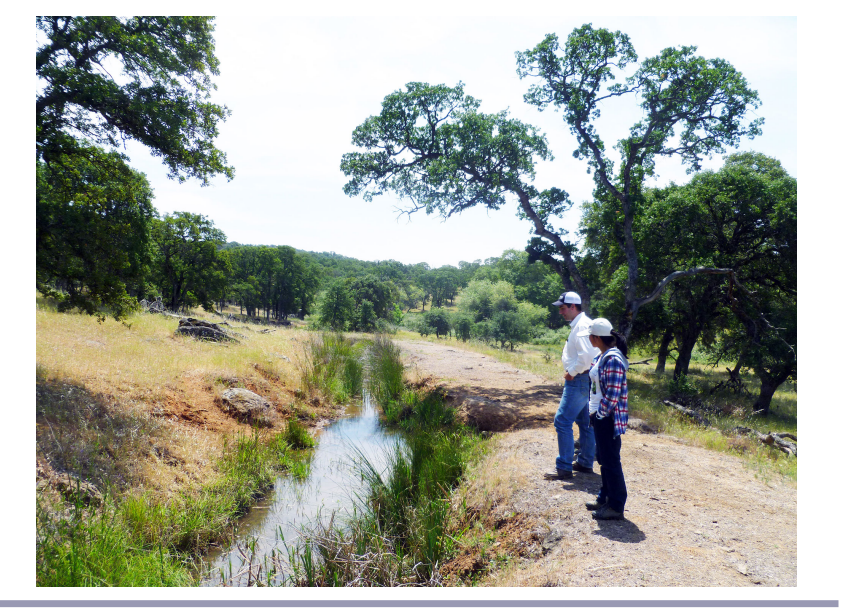

\section{METHODS}

In 2013, 18 residents and 2 irrigation district managers in the study area were interviewed to develop a mail survey. Using a snowball sampling design, initial interview contacts were recommended by local University of California Cooperative Extension staff and the California Rangeland Conservation Coalition. The mail survey was developed, pretested, and administered in 2013-2014 (Appendix I).

Within the study area, landowners from each county assessor's office were filtered to those with $\geq 1.2$ ha using ArcGIS 9.0. Properties of less than 1.2 ha were not included because they do not usually have suitable habitat. A stratified random sampling scheme was used to obtain a representative sample of landowners. Four property size strata, each with a known sampling intensity, were used to adjust for the extreme difference in the number of small versus large properties. Strata were originally selected using the American system of measurement (acres), but results are presented in metric units. Strata size was based on those used in 
other studies to facilitate comparisons (Ferranto et al. 2011). The four property size categories were 1.2 ha to $<4$ ha (property size category 1 ); 4 ha to $<20$ ha (property size category 2 ); 20 ha to $<81$ ha (property size category 3 ); and $>81$ ha (property size category 4 ). To characterize the inferred study area population, the data was weighted to match the property size distribution within the study area (Holt and Smith 1979, Atlas 2015). As a result, results from the sample can be considered representative of the study area's private properties greater than 1.2 ha, and results are analyzed with inferential statistics and discussed accordingly.

The survey instrument was designed and administered using the Dillman Tailored Design Method with a multiwave technique that included a cash incentive of a two-dollar bill in the first mailing and an online option (Dillman 1978, Dillman et al. 2009). The first mailing was sent out in the fall of 2013, in the second consecutive year of drought in California. A little over 55\%, 407 of the 734 questionnaires sent to valid addresses were filled out and returned. Only 9 used the online option. After unusable and duplicate surveys were removed, a sample of 381 respondents or $52 \%$ of total valid addresses remained. The property sizes of respondents ranged from 1.2 to 3238 ha with a total property area of 8387 ha. Not all respondents answered every question, so number of responses varies by question. Because most variables were ordinal or categorical, the Chi-square $\left(\mathrm{X}^{2}\right)$ test was used to analyze the majority of the data, while a z-test was used for column proportions for tables with more than two rows. The Student's Ttest was used for continuous variables. All statistical analyses were performed using the SPSS v22.0 software package. Differences at the $\mathrm{P}<0.05$ level were considered significant, though $\mathrm{p}$-values for all those of $\mathrm{P}<0.1$ are reported.

Appendix 1 is a full copy of the survey, although only selected questions were used for this paper. Question numbers are provided when discussing responses. Likert scale, yes and no, continuous response, and open-ended questions were asked, as were willingness to pay (Q17; how much of an increase in water price can you pay?) and willingness to accept questions (Q18; how much would you accept, and from whom, to create a wetland?). For two of the questions, about water restrictions and price hikes, each copy of the survey presented one of three water price increases as a type of choice experiment: $100 \%, 50 \%$, and $20 \%$, asking what water use actions they would take in response to a price hike for irrigation water (Q16). The same approach was used with water cutbacks, asking what they would do in response to losing $100 \%$, $50 \%$, or $20 \%$ of their water from all sources (Q19). Thus, one of three possible levels of cutback or price increase was presented to each respondent, randomly selected. Respondents were also asked what they did in response to cutbacks of any kind during the 2008 drought (Q15). Other survey topics used in this paper include land use and management, water use, reasons for using water, water sources, reasons for owning the land, attitudes toward and management of wetlands, and respondent demographics.

\section{RESULTS}

Results are representative of the entire study area, the known distribution of the California Black Rail in the foothills, for private properties of over 1.2 ha.

\section{Landowner characteristics}

Responses to questions about demographics (Q42-50) showed that landowners and managers from all walks of life responded to the survey, including those using their land purely for amenity or investment purposes. Landowners were $64 \%$ male, $82 \%$ were married or living with a partner, and $87 \%$ had a household income of less than $\$ 150,000$ annually, with $12 \%$ earning less than $\$ 30,000$. Their mean age was 62 years, similar to that found in other California surveys of rangeland landowners (Huntsinger et al. 2010, Ferranto et al. 2011). Properties had been owned for an average of 18 years. Approximately $79 \%$ of owners lived on the property all year, while $14 \%$ said they did not live on the property at all, and $7 \%$ lived there for part of the year.

The most common occupation reported was "retired," making up more than one-third of the population (Table 1; Q47). Some landowners who farm crops or own livestock did not identify themselves as farmers or ranchers, instead listing "retired," "selfemployed," or another choice as their primary occupation. Because irrigation is typically associated with pastures for livestock or with farming, categories based on questions about water use, "uses water for livestock" and "uses water for crops," are included in Table 1 (Q5). About half of the study area was owned by those using water for livestock (Table 1). Although only $11 \%$ of properties were greater than $20 \mathrm{ha}$, altogether they represented $67 \%$ of the land.

About half, 52\%, of households had not purchased water within the two years previous to the study (2011-2013; Q11; Table 1). Of those purchasing water, $49 \%$ purchased from NID, $40 \%$ purchased from BVID, and one purchased from both. Landowners also purchased from eight other districts in the area, with no more than $3 \%$ purchasing from any one of the other districts. Purchasers of water from a district were demographically similar to those not purchasing water. There was no difference in gender, marital/partnership status, or absentee ownership. Those purchasing irrigation district water, however, were on average a bit older, had owned their properties longer, had larger properties (approximately $77 \%$ of study area in aggregate; Table 1), and earned more of their household income from their property (Table 2). Farmers and ranchers, and those using water for crops and livestock, were the most likely to purchase water (Q11, Q42-50; Table 1).

\section{Sources of water for common uses}

Study area landowners most often used water for fire hazard management and gardens (Q5; Fig. 4). Well-water was used by the most landowners for fire hazard management, gardens, and watering livestock; irrigation district water was the predominant water source for irrigating pasture, filling ponds, improving wildlife habitat by supporting green vegetation, and growing crops. The amount of water used for each purpose is not known.

Black Rail habitat is most often found on properties with water features associated with an irrigation district allocation. Pipes, crops, troughs, ponds, and irrigated pastures were the most common water-related features on properties in the study area, followed by canals and ditches, shallow wetlands, and springs (Q8). As expected, landowners with water features were more likely to purchase water (Table 3), although a substantial proportion of nonwater purchasers also reported similar features. 
Table 1. Landowner occupation and use of water for livestock and crops, versus proportion of landowners purchasing irrigation water, percent household income from the land, and proportion of area owned within the foothill habitat distribution of the California Black Rail (Laterallus jamaicensis coturniculus). Bold = significant at $\mathrm{p}<0.05$ (Q47).

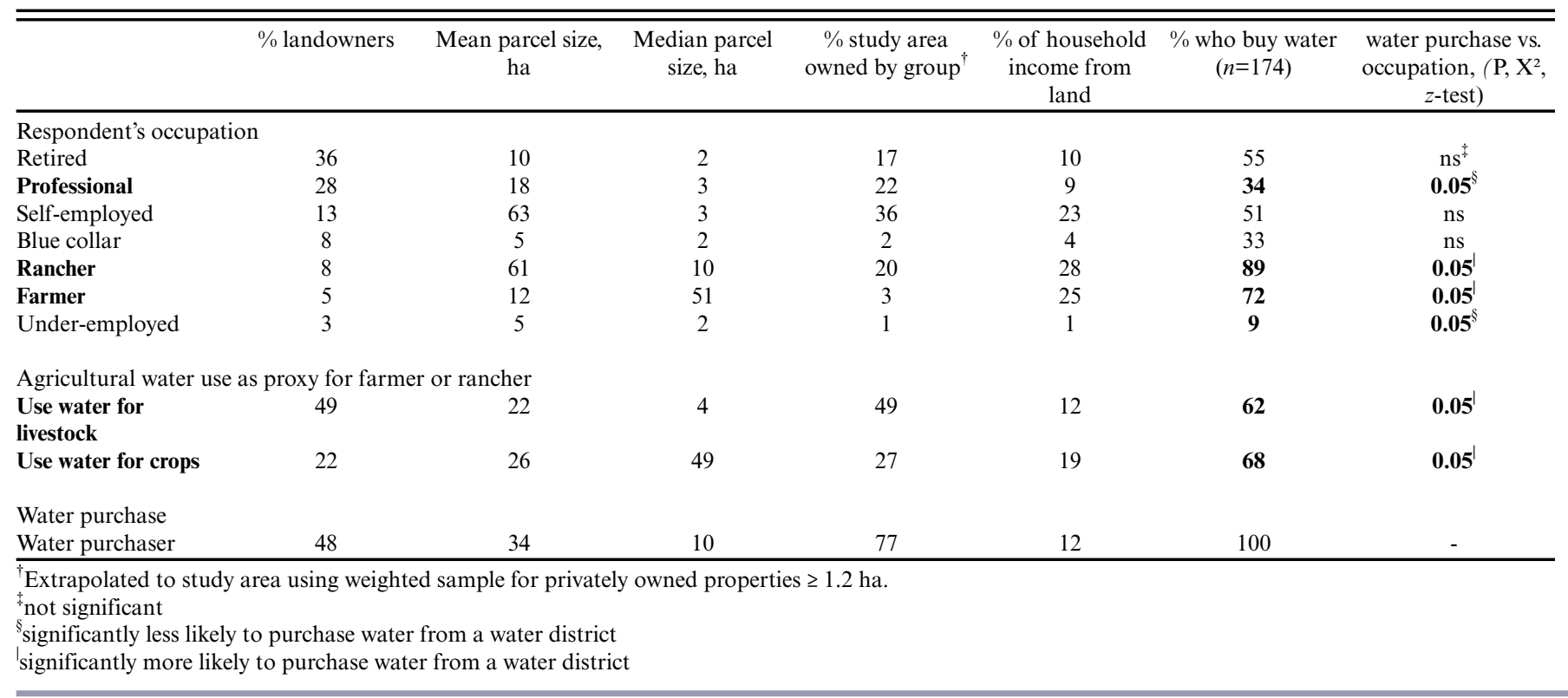

Fig. 4. Proportion of landowners using each water source for common water uses in the study area, $2013(n=381$; properties $\geq$ $1.2 \mathrm{ha}$ ). This is not a measure of the amount of water used because water for irrigated pasture, for example, is no doubt used in far larger amounts per landowner than water for watering livestock (Q5).

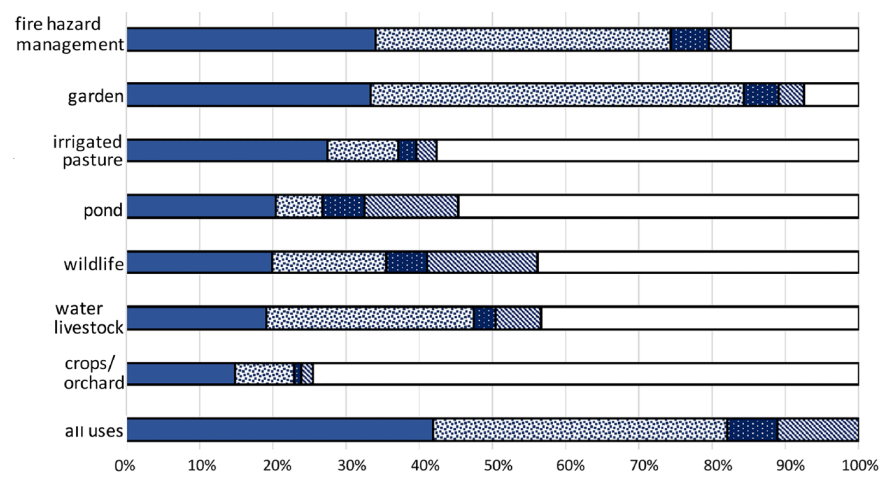

$\square$ water district 圆well $\quad$ runoff $\mathbb{\$}$ creek $\square$ does not use

\section{Ponds}

More than $33 \%$ of the properties within the distribution of Black Rails (the study area) had ponds, and over $80 \%$ of these landowners purchase water (Q6; Table 3). Ponds were generally created or enhanced by landowners. The most frequent reasons given for having a pond were for aesthetic reasons and to benefit wildlife. Bird-watching, fighting fire, maintaining property values, watering stock, and fishing were also important to many landowners (Fig.
5). For some, saving water was important because ponds can be used to store unused flow from water allocations for use after the irrigation season or when canal flows are low. Interviewees also pointed out that home insurance policies may include a discount for having a pond for firefighting.

Fig. 5. Reasons given for having a pond, asked of respondents who reported that they had a pond, 2013 ( $n=171$; properties $\geq$ 1.2 ha; Q6).

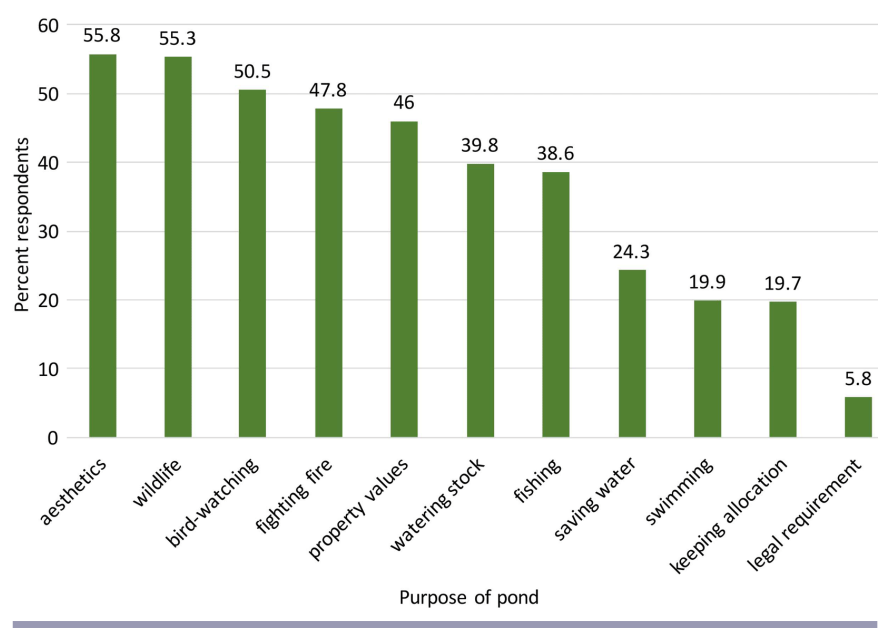

Wetlands

Images of shallow wetlands of the type used by Black Rails were provided in the survey, and nearly one-third of landowners, $32 \%$, reported having them (Q20-Q26; Table 3). Of those with shallow hillside wetlands on their property, $72 \%$ did not drain or dry them, 
Table 2. Percent annual income earned from enterprises on the land, mean property size, owner age, and length of ownership for water purchasers vs. nonpurchasers within the foothill habitat distribution of the California Black Rail (Laterallus jamaicensis coturniculus; $n=$ 363; properties $\geq 1.2$ ha; Q42-50).

\begin{tabular}{lcccc}
\hline \hline Ownership characteristic & Mean for all respondents & $\begin{array}{c}\text { Mean for those buying } \\
\text { irrigation water }(n=170)\end{array}$ & $\begin{array}{c}\text { Mean for those not buying } \\
\text { irrigation water }(n=181)\end{array}$ & $\begin{array}{c}\text { Mean vs. irrigation water } \\
\text { purchase (P, } t \text {-test })\end{array}$ \\
\hline \% of income earned from the & 8 & 12 & 4 & 0.001 \\
property & 22 & 35 & 10 & 0.001 \\
Property size (ha) & 18 & 25 & 19 & 0.006 \\
Length of ownership (yrs) & 62 & 65 & 60 & 0.001 \\
Age (yrs) & & & & \\
\hline
\end{tabular}

or fix the leaks and runoff that caused them. The main reason given was to benefit wildlife. Other reasons were because they benefit birds, do not cause problems, have aesthetic value, and provide livestock forage (Fig. 6). On the other hand, wetlands may be seen as a sign of overwatering or leaks. Wetlands may be dried when water is recycled, leaks are fixed, or the water is diverted for use elsewhere. Small wetlands may also dry when more efficient irrigation methods are used. Thus "saving water" was the main reason given for draining or drying wetlands. Other common reasons to drain or eliminate wetlands were to better use the property for unspecified purposes, and to control mosquitos (Fig. $6)$.

\section{Water use decisions}

Landowners were asked what influenced their water use decisions (Q4). Decisions were influenced most by the goals of saving water, enjoying the property, wildfire danger, maintaining or increasing property values, and retaining their water allocation, as well as by the water price (Fig. 7). Creating or maintaining wildlife habitat was not an option included in this question.

Fig. 6. Reasons given by respondents for why they do and do not drain wetlands, for those who have shallow hillside wetlands, categories not mutually exclusive. Of the $32 \%$ of respondents having such wetlands, $72 \%$ do not drain or manipulate them $(n=$ 381 ; properties $\geq 1.2$ ha; Q20-26).

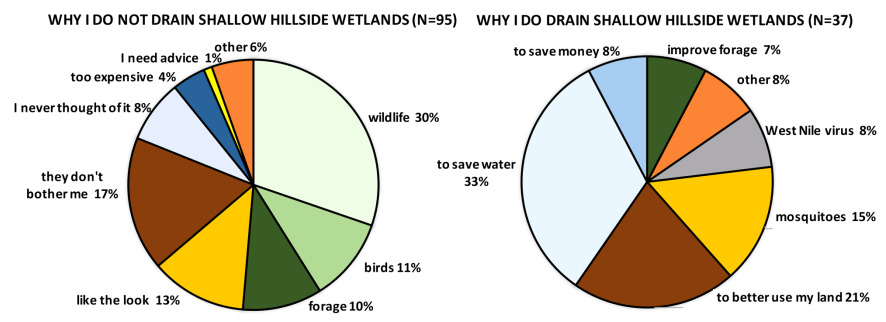

Impacts of irrigation district cutbacks

Irrigation district purchasers experiencing water cutbacks in 2008 were asked about their adaptation strategy (Q15) $(n=92)$. Almost all reported having taken some action (Fig. 8). Reducing water use for irrigated pastures, substituting well water for irrigation district water, and reduced area of gardens and crops were the most common actions taken. Approximately $10 \%$ repaired leaks in ditches, pipes, dams, or ponds. Few indicated they were able to find other grazing land or purchase water from other sources. All landowners were asked what they would do if their water supply, regardless of source, was reduced in the future $(\mathrm{Q} 19 ; n=334)$. The most common responses were to reduce crop and irrigated pasture area, and to use less water on irrigated pasture. The owners of approximately $5 \%$ of the study area said they would have to sell their land.

Fig. 7. Percent water district users reporting the following as an important influence on their water use decisions $(n=181$; properties $\geq 1.2 \mathrm{ha} ; \mathrm{Q} 4$ ).

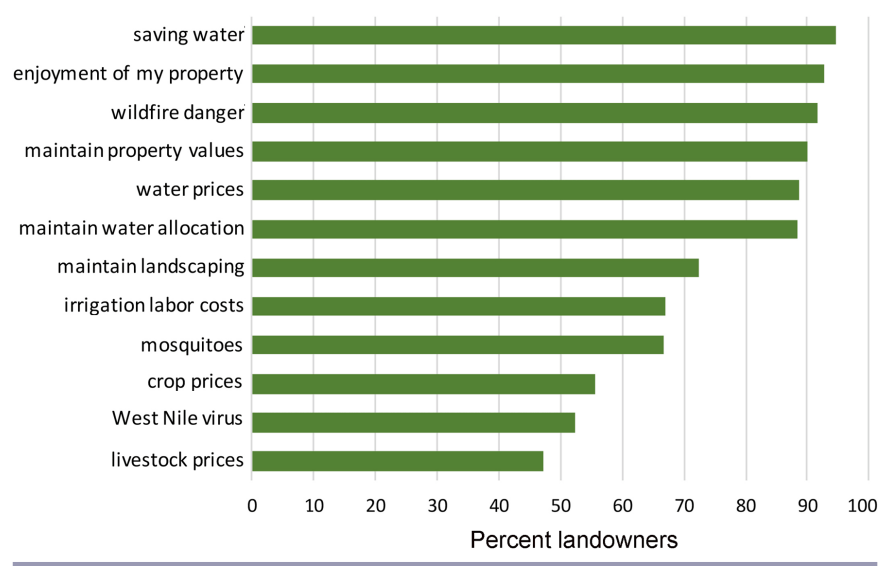

Fig. 8. How respondent adapted to 2008 cutbacks $(n=92$; properties $\geq 1.2$ ha; Q15).

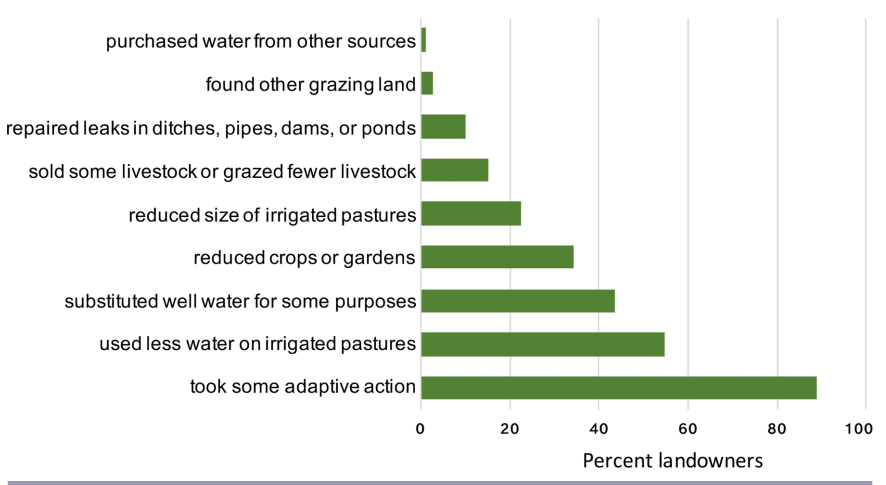

An average of $75 \%$ of landowners said they would need to take adaptive action in response to price increases: approximately $31 \%$ would reduce water to pastures; $20 \%$ would reduce pasture area; 
Table 3. Water or water-using features on respondent properties versus whether or not they purchase irrigation water, listed from most to least common. Through leaks or runoff, or by their presence, these features may provide habitat for the California Black Rail(Laterallus jamaicensis coturniculus) and other wildlife. Springs, wetlands, or ponds may or may not be supported by irrigation water but more frequently occur on the properties of those purchasing water district water ( $n=381$; properties $\geq 1.2 \mathrm{ha}$; Q8).

\begin{tabular}{lccc}
\hline \hline $\begin{array}{l}\text { Respondent's property has the } \\
\text { following water or water-using } \\
\text { features }\end{array}$ & $\begin{array}{c}\text { \% of landowners with water feature } \\
\text { \%o of landowners with water feature } \\
\text { who purchase irrigation water }\left(n=\begin{array}{c}\text { Percent of landowners purchasing } \\
\text { water vs. having the water feature }(\mathrm{P}, \\
\left.\mathrm{X}^{2}\right)\end{array}\right.\end{array}$ & 0.001 \\
\hline Pipes & 44 & 76 & 0.001 \\
Irrigated crops & 40 & 69 & 0.001 \\
Trough & 40 & 69 & 0.001 \\
Ponds & 36 & 83 & 0.001 \\
Irrigated pastures & 36 & 85 & 0.001 \\
Canal or ditch & 31 & 69 & 0.001 \\
Shallow wetland & 32 & 62 & 0.018 \\
Springs & 18 & 61 & \\
\hline
\end{tabular}

$29 \%$ would substitute with well-water; $8 \%$ would repair leaks; and $0.5 \%$ would purchase water from other sources (Q16; $n=183$ ). Although there was no significant difference among responses to the three stated price increases in terms of water use, the amount of water purchased was sensitive to price. As water prices increased by $20 \%, 50 \%$, or $100 \%$, the proportion of respondents saying they would reduce water purchased was approximately $16 \%, 41 \%$, and $51 \%$, respectively $\left(\mathrm{P}<0.001, \mathrm{X}^{2}, n=381\right)$.

In an open-ended question, those who used irrigation district water were asked how much water prices would have to increase before they changed their water use (Q17). The mean was a $25 \%$ price increase, with responses ranging from an increase of $1 \%$ to $200 \%$ (sd $=30 ; n=113$ ). Nearly $20 \%$ said they could not adapt to this increase, while those able to adapt reported that they would reduce water going to pastures, house landscaping, and ponds (Q18; Fig. 9).

Fig. 9. Responses to the question "which water use would water district users change first if water prices exceeded the maximum price increase they could handle without changing anything?" (open-ended question Q17; $n=118$; properties $\geq 1$.2ha).

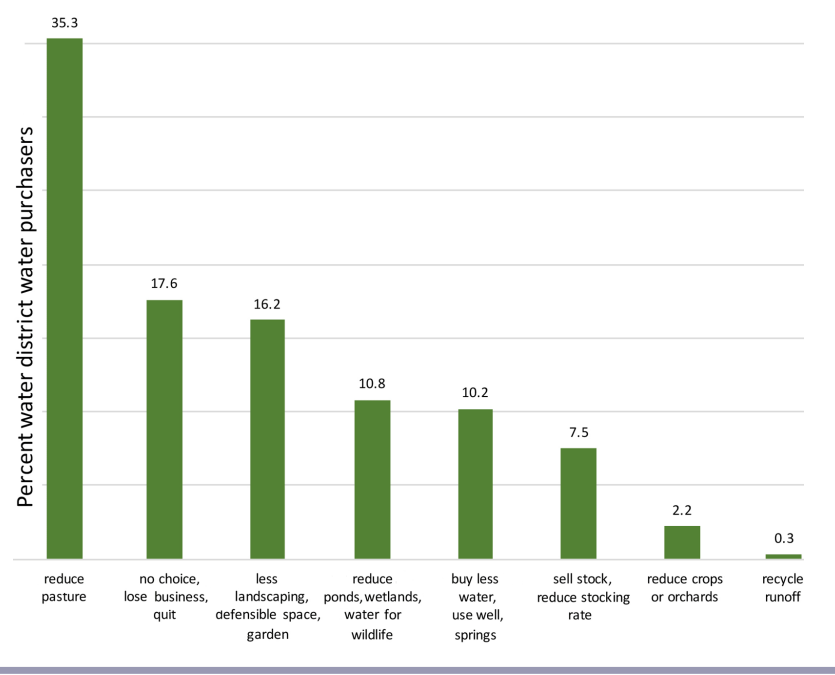

\section{Dependence on water}

The vast majority of owners were concerned about having enough water, and believed that it was important to their ability to use their property (Q3; Table 4). Comparing those who do and do not purchase water, those who purchase irrigation district water were more likely to agree they had enough water but were more apprehensive about being able to adapt to water reductions than those not purchasing water, and were more concerned about the impact of drought on their ability to make a living (Table 4).

\section{DISCUSSION}

The landowners and managers in this study are similar to those in other studies of California hardwood rangeland owners and managers (Huntsinger et al. 2010, Oviedo et al. 2012, Ferranto et al. 2011, 2014). They value the diverse ecosystem services produced on their properties, and they use water to enhance many of these services. The landscape is increasingly postproductivist and most do not make the majority of their income from their land (Huntsinger et al. 2010). More than a third are retired. The ranchers and farmers in the area continue their production activities in a matrix of smaller properties owned by relative "newcomers" with different goals for their properties. Because survey responses are extrapolated to the study area as a whole for private properties greater than 1.2 ha, we know that irrigation district users and livestock owners together control the vast majority of the private land and Black Rail habitat in the study area. Irrigation district customers made up less than half of landowners but owned $75 \%$ of the total land in the study area. Those with livestock, many of whom are also irrigation district purchasers, owned about $50 \%$ of the study area, and were more likely to use irrigation in a way that created wildlife habitat than were those without stock. Policies that influence agricultural uses of land and availability of irrigation district water will therefore have a very strong influence on Black Rails and other wetlanddependent species within the foothill habitat distribution of the Black Rail.

The untreated water sold by irrigation districts serves many purposes beyond commercial agriculture. The single most common motivator of water use by landowners was to mitigate wildfire risk by maintaining green vegetation through the dry season-part of "defensible space" - and by creating ponds that could be used to fight fires. Landowners also commonly used 
Table 4. Percent of respondents purchasing and not purchasing irrigation water who agree with the listed statements about water use and availability $(n=367$; properties $\geq 1.2$ ha; Q3).

\begin{tabular}{|c|c|c|c|c|}
\hline $\begin{array}{l}\text { Respondent agrees with } \\
\text { statement below: }\end{array}$ & $\begin{array}{l}\% \text { of those not buying } \\
\text { irrigation water }(n=190)\end{array}$ & $\begin{array}{c}\% \text { of irrigation water buyers } \\
(n=177)\end{array}$ & $\mathrm{P}, \mathrm{X}^{2}$ & $\%$ of all landowners $(n=367)$ \\
\hline $\begin{array}{l}\text { I am concerned about } \\
\text { possible future water } \\
\text { shortages. }\end{array}$ & 92 & 99 & 0.001 & 96 \\
\hline $\begin{array}{l}\text { Having less water would } \\
\text { reduce my ability to use my } \\
\text { property. }\end{array}$ & 86 & 94 & 0.022 & 90 \\
\hline $\begin{array}{l}\text { It is difficult to get new or } \\
\text { added water from a water } \\
\text { district. }\end{array}$ & 89 & 78 & 0.044 & 83 \\
\hline $\begin{array}{l}\text { I have plenty of water for } \\
\text { my property. }\end{array}$ & 64 & 82 & 0.001 & 73 \\
\hline $\begin{array}{l}\text { Drought can have a big } \\
\text { impact on my ability to } \\
\text { make a living. }\end{array}$ & 28 & 49 & 0.001 & 38 \\
\hline $\begin{array}{l}\text { I can easily adapt to a water } \\
\text { shortage. }\end{array}$ & 34 & 14 & 0.001 & 24 \\
\hline
\end{tabular}

District water to enhance enjoyment of their property for recreation and aesthetics, using it for landscaping, gardening, attracting wildlife, raising horses, swimming, and so forth. Irrigation district infrastructure itself provides cultural ecosystem services for residents. A coalition called "Save Our Historic Canals" is active in the study area and works to reduce the ongoing piping and lining of canals. Residents prefer the old earthen canals to pipes or concrete canals because they provide valued aesthetic and ecological services: flowing water and greenery along the canal, and wildlife habitat and potential fire breaks from seeps downhill of the canal.

Both wetland-dependent wildlife and landowner activities are buffered from fluctuations in rainfall and snowpack by irrigation districts. In the third year of severe drought the overwhelming majority of water purchasers responded that they still had plenty of water for their property. At the same time, their dependence on activities supported by abundant water caused them to fear water reductions or water price increases, as was also found by Welsh et al. (2013). A waiting list for new water allocation maintains pressure on current allocation holders to keep what they have, whether they need it or not. Allocations can be reappropriated by the irrigation district if the landowner is found to be either wasting water or failing to put their allocation to "beneficial use," encouraging landowners to find diverse uses for water. The situation is summed up in this comment from a survey: "I've always purchased twice as much water as I need... my insurance policy. If things got really bad, I'd change my pump to half its capacity and be just fine."

On the other hand, users are pushed to conserve water by political and economic forces, including the Governor's mandate to reduce water use by $20 \%$, rising prices, and a sense of social responsibility as the impacts of the drought fill the media. The fact that $80 \%$ of California's water use is consumed by agriculture is poorly understood by urban populations and often blamed for water shortages. Overall, findings suggest that many landowners are inclined to implement water conservation efforts in response to drought and social pressure, but that cutting back water use also reduces benefits they enjoy from their land.

\section{Conservation of water versus wildlife}

Research has shown that Black Rails in the Sierra foothills primarily occupy wetlands that receive water, intentionally or not, supplied by irrigation district infrastructure (Richmond et al. 2010). It is not clear if these irrigated wetlands are replacing other wetlands that have been lost, or if they are a novel resource that has allowed Black Rails to expand their range. In either case, a reduction in the amount of water applied to the landscape translates to a loss of habitat, a direct conflict between conservation of water and conservation of a threatened species. How the water is conserved makes a difference, however, because not all water use in the study area contributes to the wetlands used by Black Rails. Understanding the hydrological effects of specific water conservation efforts will be important for designing water policy that does not negatively impact Black Rails and other wildlife.

Water use restrictions such as those instituted by Governor Brown in 2015 affect how landowners apply water to their properties. The most common responses chosen to a hypothetical cutback in irrigation district water were to reduce the area of, or water applied to, irrigated pastures and crops, which in turn will reduce the leaks and tailwater feeding small wetlands. Landowner water management affects wetlands more directly as well. Saving water was the major motivation landowners reported for stopping leaks and drying shallow wetlands, while encouraging wildlife was the main reason given for keeping wetlands (Fig. 6). This vividly illustrates the trade-offs between wetland wildlife and irrigation water conservation, and between water-supported ecosystem services valued by landowners and the State's goal of reducing water use. Some landowners commented that if they reduced water use, wildlife would be harmed. This was exemplified by statements such as the "pond would suffer I suppose - it supports a lot of wildlife so I would hate any change there." Further, there was recognition of the connection between shallow wetlands and wildlife, with a respondent commenting that "wildlife need their puddles and streams."

A reduction in irrigation district water, due either to severe drought or to conservation policy, might cause landowners to 
shift to well-water, as $50 \%$ of landowners did in the 2008 cutbacks. Groundwater use has only very recently begun to be regulated in California and the effects are not yet clear (Bates 2012). Both BVID and NID, like many other irrigation districts, capture snowmelt and winter rains in reservoirs for summer use. If landowners were to switch from irrigation district water to groundwater, not only would pumping of groundwater increase, but groundwater recharge from irrigation water would decrease. In addition, most of the study area has a fractured hard-rock aquifer, meaning that groundwater supplies are highly localized and labile. Therefore, aquifers are usually small and need continuous recharge, and neighboring wells may compete for water. Half of all wells in this type of geology yield only enough water for individual domestic purposes (CDWR 2011). In addition, the costs of electricity for pumping typically prohibits using well water for large-scale agriculture in the foothills.

\section{Water transfers may set off a drying cycle}

Irrigation districts in the study area are constrained by laws requiring that water fees only reflect the cost of storing and delivering water, including status quo maintenance. Fees cannot be raised to fund contingencies or material upgrades in infrastructure. As a result, irrigation districts are forced to find the necessary capital for infrastructural improvements elsewhere. The two most common funding sources are local bonds and "water transfers," the one-time sale of large volumes of "excess" water to other irrigation districts or to municipalities outside the district, most often at a higher price than can be charged within the district. Improving water delivery efficiency by reducing leakage may free up more water for transfers, providing a monetary incentive for local districts to tighten the infrastructure transporting water to local customers.

If infrastructure is made more efficient by piping, lining canals or fixing leaks, then more water is available for new residential developments, as well as for water transfers. Transfer sales can then fund efficiency improvements to water delivery infrastructure, further reducing water leaking to the local ecosystem. This local dewatering is an unintended consequence of water conservation efforts, which place even further pressure on the already drought-stressed landscape and the wildlife species that rely on the ponds and wetlands created by "leaky" water infrastructure. The predictions of more climate-induced droughts will exacerbate this aridifying feedback loop, creating more incentives to conserve water and reducing wildlife habitat.

\section{Speculation on solutions}

We argue that using water to maintain vital habitat should not be considered "waste" at district or landowner levels. However, some ponds and wetlands may provide more valuable habitats than others. Some wetlands could be allowed to dry during drought and then could be restored afterwards in an adaptive management strategy (Downard et al. 2014). Inventory and monitoring could be used to select the high priority habitats that should be maintained through droughts.

Irrigation districts, landowners, and property managers need outreach, education, incentives, and innovative programs to protect wildlife habitat while reducing water use. Existing sources of incentives funding for landowners could be tapped. For example, the Environmental Quality Incentives Program (EQIP) is a federal program that provides cost share to landowners carrying out environmentally positive improvements, such as maintaining stockponds valuable to endangered amphibians (USDA NRCS CA 2016). The landowner agrees to carry out maintenance activities in ways that protect the animals. EQIP money could be used to efficiently channel irrigation and pasture runoff into wetlands that can support Black Rails. As another example, land developers are often required by local governments to provide funding for conservation mitigation before they can implement a project such as a residential development, an ongoing activity in the study area. Such funding could be targeted at maintaining wetlands and encouraging wildlife-friendly water management.

According to irrigation district employees interviewed in this study, the districts do not currently survey for wetlands used by Black Rails prior to fixing a seep or leak. Such activity is considered routine maintenance and has a categorical exemption from the California Environmental Quality Act, which would otherwise require monitoring for potential negative impacts. This practice seems to apply to infrastructural improvements, such as lining or piping canals, as well, meaning that Black Rails and other wildlife are effectively invisible when it comes to managing anthropogenic wetlands. Barring an unforeseen legal challenge, this situation is likely to continue as irrigation districts increasingly replace earthen canals with more "efficient" infrastructure in an effort to conserve water.

\section{CONCLUSIONS}

The wetlands created by irrigating pastures and filling ponds are a form of ecosystem engineering created for animal husbandry or landowner enjoyment that also provides habitat for wildlife (Jones et al. 1994, Huntsinger and Oviedo 2014). As water becomes decreasingly plentiful in California, the conservation challenge ahead is balancing one good (water conservation) with another (habitat conservation). Unfortunately, at the present time water conservation has more political pressure behind it than protection of our considerable and increasingly important anthropogenic wildlife habitat. Heavy-handed state intervention to conserve water is likely to create a multitude of unintended consequences, including a loss of biodiversity and environmental quality.

New regulations on how irrigation districts transport and allocate water within and beyond their jurisdictions may substantially reshape the nexus through which water-based ecosystem services are provided. Governor Brown's Executive Order of 1 April 2015, requires that agricultural water users report more information on water use to state regulators, increasing the state's ability to enforce against illegal diversions, waste, and unreasonable use of water. Further, the order simplifies the review and approval process for voluntary water transfers, and incentivizes the development of new technology to make California more water efficient (State of California 2015). These policies will likely accelerate the lining and piping of earthen canals that currently sustain green vegetation through the summer, recharge groundwater, and create small wetlands through seepage. Although wetland areas enjoy some environmental protections, many of the small wetlands used by Black Rails are too small or shallow to be recognized by most people as wetlands. They are not only incidentally created, they are, for policy and regulatory 
purposes, largely ignored (Hruska et al. 2015). In fact, during the course of this study a leak was fixed on public land used as a wildlife reserve, eliminating known Black Rail habitat.

Absent policy and programs that regulate or incentivize irrigation district protection of the small wetland habitats produced by seeps and leaks, the fate of many small wetlands will depend on the decisions of individual landowners about how to manage water. Irrigation in the foothills provides many "nonmarket" ecosystem services that are rarely accounted for in assessments of irrigation systems (Bakker and Matsuno 2001) but nonetheless have a strong influence on water use decisions by landowners. For example, many survey respondents purchase irrigation district water despite making little or no money from the uses of that water. Landowners grow home gardens, raise horses or other stock for pleasure and/or meat for the household, create ponds for recreation and visual appeal, and maintain green vegetation through the dry summer to reduce wildfire risk. These uses of water, which are part of the appeal of rural living for many survey respondents, contribute to the anthropogenic landscape that supports Black Rails. They are also "nonproductive" uses whose value to the local environment or residents may not be recognized by state regulators or growing cities on the coast looking to increase their water supply.

Water conservation policy requiring blanket use reductions does not fit well with the limitations of foothills irrigation district infrastructure or allocation policies. Landowners are leery of giving up part or all of their allocations during a drought in case they cannot get it back, and irrigation districts have a difficult time knowing how to regulate flow in infrastructure systems that operate only when full. In both 2014 and 2015, NID offered customers the option of declining water for the year, while retaining the right to purchase the full allocation of water in the future. This policy, and more intensive monitoring of flows out of district reservoirs, has proven an important source of conservation for irrigation districts during the drought.

Though it may be necessary to conserve water during drought, permanent dewatering undermines the social-ecological system that provides wetland habitat. These wetlands must somehow be made visible to irrigation districts and state regulators if they are to be protected during water conservation efforts. Landowners largely appreciate wildlife and the green vegetation of small anthropogenic wetlands, but are not currently incentivized to maintain them if price increases or water cutbacks loom.

Current and future demand for water, and conflicts over how it should be allocated, creates pressure on irrigation districts to increase the efficiency of water delivery systems, and on landowners to reduce their use of water. Droughts are likely to make water conservation more necessary, and urban growth increases demand for water locally, as well as for lucrative water transfers. The unintended consequence is a loss of wetlands important to the California Black Rail, and, in the opinion of many residents, an increase in fire hazard as greenery supported by leaky canals and runoff, as well as by deliberate application by residents, dries and the climate continues to change.

Policy and governance frameworks for future water conservation should include recognizing that providing wildlife habitat is an important, beneficial use of water, and prioritizing habitat areas to maintain in times of drought. A large portion of Black Rail habitat results from the intersection of plentiful water, a particular form of agriculture, a historical event - in this case the Gold Rush - and the needs of a threatened bird. This history should be recognized and leveraged rather than ignored in a rush to "save" water by unraveling the social-ecological system that created this landscape.

Responses to this article can be read online at: http://www.ecologyandsociety.org/issues/responses. $\mathrm{php} / 9217$

\section{Acknowledgments:}

We first acknowledge the many people who took the time to fill out our survey and to meet with us. We also thank our reviewers for their helpful suggestions and edits. This project was funded as part of the NSF Coupled Human Natural Systems Program, Project Award Number 1115069, Wetlands in a Working Landscape, with Professor Steve Beissinger as Principal Investigator. We thank Graduate Student Researchers Luke Macauley and Gareth Fisher for their help with GIS analysis and field interviews; Graduate Student Investigator Nathan Van Schmidt, who helped us define and measure the study area; Lesa Osterholm for her reviews and advice; and Peking University visiting scholar Li Yanbo for her help with fieldwork. The College of Natural Resources' Sponsored Projects in Undergraduate Research supported Andy Wong to help with GIS analysis. J.L. Oviedo's involvement in this study was also funded by the Salvador de Madariaga program (grant number PRX16/00452) of the Spanish Ministry of Education, Culture and Sports.

\section{LITERATURE CITED}

Aigner, P. A., J. Tecklin, and C. E. Koehler. 1995. Probable breeding population of the Black Rail in Yuba County, California. Western Birds 26(3):157-160.

Atlas. 2015. Post-stratification weights. University of Illinois at Urbana-Champaign, Champaign, Illinois, USA. [online] URL: http://www.atlas.illinois.edu/support/stats/resources/spss/create-poststratification-weights-for-survery-analysis.pdf

Bakker, M., and Y. Matsuno. 2001. A framework for valuing ecological services of irrigation water: a case of an irrigationwetland system in Sri Lanka. Irrigation and Drainage Systems 15 (2):99-115. http://dx.doi.org/10.1023/A:1012933829937

Bates, S. 2012. Bridging the governance gap: emerging strategies to integrate water and land use planning. Natural Resources Journal 52:61-97.

Byrd, K. B., L. E. Flint, P. Alvarez, C. F. Casey, B. M. Sleeter, C. E. Soulard, A. L. Flint, and T. L. Sohl. 2015. Integrated climate and land use change scenarios for California rangeland ecosystem services: wildlife habitat, soil carbon, and water supply. Landscape Ecology 30:729-750. http://dx.doi.org/10.1007/s10980-015-0159-7

CAL FIRE. 2010. California's forests and rangelands: 2010 assessment. California Department of Forestry \& Fire Protection, California, USA. [online] URL: http://frap.fire.ca. gov/data/assessment2010/pdfs/california forest assessment nov22. pdf 
California Department of Water Resources (CDWR). 2011. Water facts no. 1: ground water in fractured hard rock. State of California, Sacramento, California, USA. [online] URL: http:// www.water.ca.gov/waterconditions/docs/water_facts_1.pdf

California Legislative Analyst's Office (CA-LAO). 2002. Water special districts: A look at governance and public participation. CALAO, Sacramento, California, USA. [online] URL: http://www. lao.ca.gov/2002/water districts/special water districts.html

Dillman, D. A. 1978. Mail and telephone surveys: the total design method. John Wiley \& Sons, New York, New York, USA.

Dillman, D. A., J. D. Smyth, and L. M. Christian. 2009. Internet, mail, and mixed-mode surveys: the tailored design method, third edition. John Wiley \& Sons, Hoboken, New Jersey, USA.

Downard, R., J. Endter-Wada, and K. M. Kettenring. 2014. Adaptive wetland management in an uncertain and changing arid environment. Ecology and Society 19(2):23. http://dx.doi. org/10.5751/es-06412-190223

Ferranto, S., L. Huntsinger, C. Getz, G. Nakamura, W. Stewart, S. Drill, Y. Valachovic, M. DeLasaux, and M. Kelly. 2011. Forest and rangeland owners value land for natural amenities and as financial investment. California Agriculture 65:184-191. http://dx. doi.org/10.3733/ca.v065n04p184

Ferranto, S., L. Huntsinger, and M. Kelly. 2014. Sustaining ecosystem services from private lands in California: the role of the landowner. Rangelands 36(5):44-51. http://dx.doi.org/10.2111/ rangelands-d-14-00023.1

Fleming, W. M., J. A. Rivera, A. Miller, and M. Piccarello. 2014. Ecosystem services of traditional irrigation systems in northern New Mexico, USA. International Journal of Biodiversity Science, Ecosystem Services and Management 10:343-350. http://dx.doi. org/10.1080/21513732.2014.977953

Girard, P., J. Y. Takekawa, and S. R. Beissinger. 2010. Uncloaking a cryptic, threatened rail with molecular markers: origins, connectivity and demography of a recently-discovered population. Conservation Genetics 11:2409-2418. http://dx.doi. org/10.1007/s10592-010-0126-4

Holt, D., and T. M. F. Smith. 1979. Post stratification. Journal of the Royal Statistical Society A 142:33-46. http://dx.doi. org/10.2307/2344652

Hruska, T. V., L. Huntsinger, J. L. Oviedo. 2015. An accidental resource: the social ecological system framework applied to small wetlands in Sierran foothill oak woodlands. Pages 231-238 in R. B. Standiford and K. L. Purcell, technical coordinators. Proceedings of the seventh California oak symposium: managing oak woodlands in a dynamic world. General Technical Report PSW-GTR-251. Department of Agriculture, Forest Service, Pacific Southwest Research Station, Berkeley, California, USA. [online] URL; http://www.treesearch.fs.fed.us/pubs/49991

Huntsinger, L., M. Johnson, M. Stafford, and J. Fried. 2010. Hardwood rangeland landowners in California from 1985 to 2004: production, ecosystem services, and permanence. Rangeland Ecology and Management 63:324-334. http://dx.doi. org/10.2111/08-166.1
Huntsinger, L., and J. L. Oviedo. 2014. Ecosystem services are social-ecological services in a traditional pastoral system: the case of California's Mediterranean rangelands. Ecology and Society 19(1):8. http://dx.doi.org/10.5751/ES-06143-190108

Jones, C. G., J. H. Lawton, and M. Shachak. 1994. Organisms as ecosystem engineers. Oikos 69:373-386. http://dx.doi.org/10.2307/3545850

Lewis, D., M. J. Singer, R. A. Dahlgren, and K. W. Tate. 2000. Hydrology in a California oak woodland watershed: a 17-year study. Journal of Hydrology 240:106-117. http://dx.doi. org/10.1016/S0022-1694(00)00337-1

Luckey, R. R., and J. C. Cannia. 2006. Groundwater flow model of the western model unit of the Nebraska Cooperative Hydrology Study (COHYST) area. Cooperative Hydrology Study, Lincoln, Nebraska, USA. [online] URL: http://cohyst.dnr.ne.gov/adobe/ dc012WMU GFMR 060519.pdf

O’Geen, A. T., R. A. Dahlgren, A. Swarowsky, K. W. Tate, D. J. Lewis, and M. J. Singer. 2010. Research connects soil hydrology and stream water chemistry in California oak woodlands. California Agriculture 64:78-84. http://dx.doi.org/10.3733/ca. $\mathrm{v} 064 \mathrm{n} 02 \mathrm{p} 78$

Oviedo, J. L., L. Huntsinger, P. Campos, and A. Caparros. 2012. Income value of private amenities assessed in California oak woodlands. California Agriculture 66:91-96. http://dx.doi. org/10.3733/ca.v066n03p91

Peck, D. E., and J. R. Lovvorn. 2001. The importance of flood irrigation in water supply to wetlands in the Laramie Basin, Wyoming, USA. Wetlands 21(3):370-378. http://dx.doi. org/10.1672/0277-5212(2001)021[0370:tiofii]2.0.co;2

Polade, S. D., D. W. Pierce, D. R. Cayan, A. Gershunov, and M. D. Dettinger. 2014. The key role of dry days in changing regional climate and precipitation regimes. Scientific Reports 4:4364. http://dx.doi.org/10.1038/srep04364

Richmond, O. M., J. Tecklin, and S. R. Beissinger. 2008. Distribution of California Black Rails in the Sierra Nevada foothills. Journal of Field Ornithology 79:381-390. http://dx.doi. org/10.1111/j.1557-9263.2008.00195.x

Richmond, O. M. W., S. K. Chen, B. B. Risk, J. Tecklin, and S. R. Beissinger. 2010. California Black Rails depend on irrigationfed wetlands in the Sierra Nevada foothills. California Agriculture 64:85-93. http://dx.doi.org/10.3733/ca.v064n02p85

State of California. 2014. Governor Brown declares drought state of emergency. 17 January 2014. Office of the Governor, Sacramento, California, USA. [online] URL: https://www.gov.ca. gov/news.php?id=18368

State of California. 2015. Governor Brown directs first ever statewide mandatory water reductions. 1 April 2015. Office of the Governor, Sacramento, California, USA. [online] URL: https:// www.gov.ca.gov/news.php?id=18913

Sueltenfuss, J. P., D. J. Cooper, R. L. Knight, and R. M. Waskom. 2013. The creation and maintenance of wetland ecosystems from irrigation canal and reservoir seepage in a semi-arid landscape. Wetlands 33(5):799-810. http://dx.doi.org/10.1007/s13157-013-0437-6 
United States Department of Agriculture Natural Resources Conservation Service California (USDA NRCS CA). 2016. Wildlife-friendly livestock pond fund pool. USDA NRCS CA, Davis, California, USA. [online] URL: https://www.nrcs.usda. gov/wps/portal/nrcs/detail/ca/programs/financial/eqip/?cid= stelprdb1247020

United States Environmental Protection Agency (US EPA). 2009.

Land-use scenarios: national-scale housing-density scenarios consistent with climate change storylines (final report). EPA/600/ R-08/076f. Environmental Protection Agency, Washington, D.C., USA. [online] URL: https://cfpub.epa.gov/ncea/risk/recordisplay. $\underline{\mathrm{cfm}}$ ?deid $=203458 \&$ CFID $=72173787 \&$ CFTOKEN $=85880738$

United States Geological Survey (USGS). 2015. California drought. USGS, Reston, Virginia, USA. [online] URL: http://ca. water.usgs.gov/data/drought/

Walker, P. A., S. J. Marvin, and L. P. Fortmann. 2003. Landscape changes in Nevada County reflect social and ecological transition. California Agriculture 57:115-121. http://dx.doi.org/10.3733/ca. $\underline{\mathrm{v} 057 \mathrm{n} 04 \mathrm{p} 115}$

Weiner, J. D., K. A. Dwire, S. K. Skagen, R. R. Crifsi, and D. Yates. 2008. Riparian ecosystem consequences of water redistribution along the Colorado Front Range. Water Resources Impact 10(3). [online] URL: http://www.fs.fed.us/rm/pubs other/ rmrs 2008 wiener_j001.pdf

Welsh, L. W., J. Endter-Wada, R. Downard, and K. M. Kettenring. 2013. Developing adaptive capacity to droughts: the rationality of locality. Ecology and Society 18(2):7. http://dx.doi. org/10.5751/es-05484-180207 

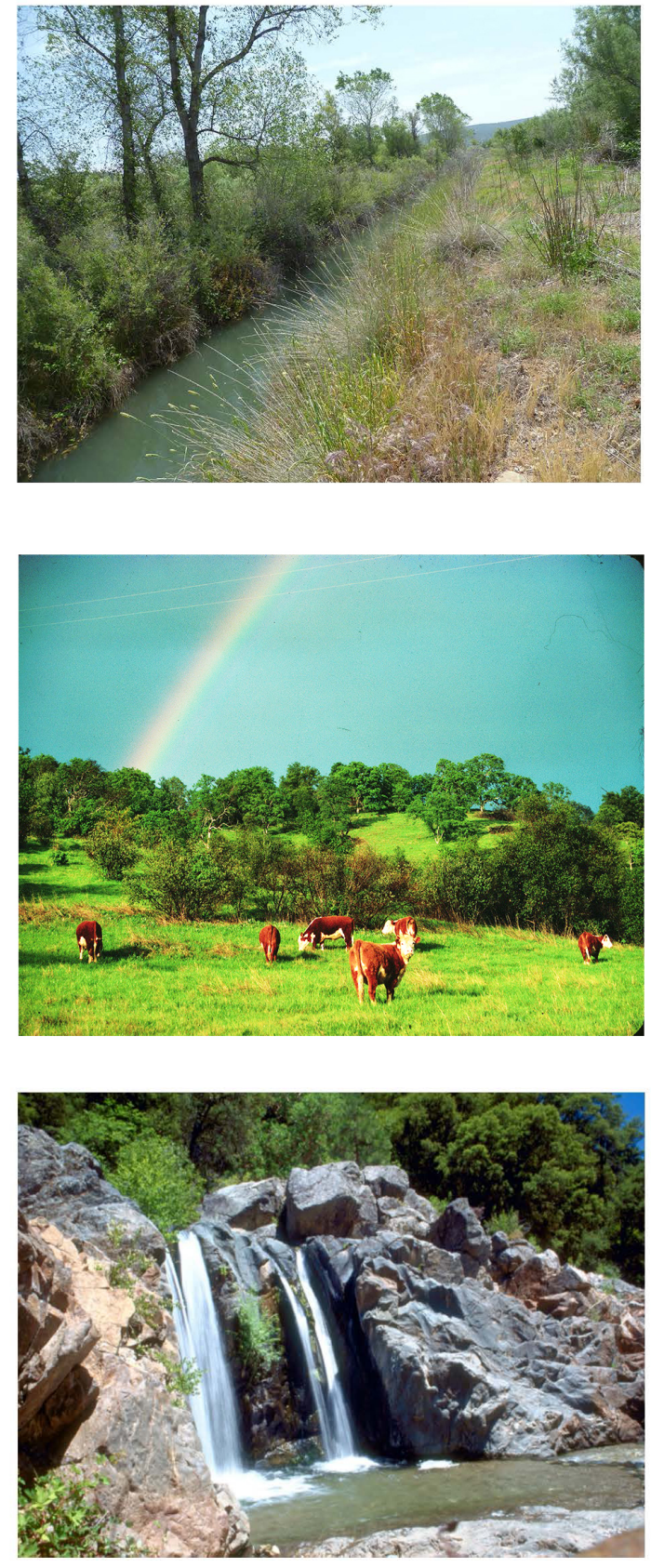

\section{Will there be enough water for you?}

\section{A survey of water use and management in foothill communities}

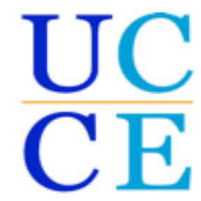

University of California

Agriculture and Natural Resources Cooperative Extension 
Please help us--we need to know how water is important to you.

Please tell us how water availability and price, and concerns about West Nile Virus, affect your use of water and your ability to use your property.

This information is important to local water managers, policymakers, and researchers trying to understand the potential consequences of water decisions on agriculture, vegetation, wildlife, and communities in the foothills.

We hope to reach Yuba, Butte, and Nevada County landowners. If you are not a Yuba, Butte, or Nevada County landowner, please check the box below and return the questionnaire in the pre-paid envelope.

\section{DO NOT OWN LAND IN YUBA, BUTTE, OR NEVADA COUNTY}

If you do own land in Yuba, Butte or Nevada County, please ask the person most involved in managing your land to fill out this survey and return it in the enclosed prepaid envelope.

This survey is anonymous. A questionnaire number is printed on the back cover so that we can check your name off the mailing list when your questionnaire is returned. The list of names is then destroyed so that names cannot be connected to the results. If you don't want to answer a question or you don't know how to answer, just skip it. My phone number is below so feel free to call me to discuss this survey if you like.

Thank you, 
1. Please rank which group has the most control over water use on your property. Use 1 for most control and 4 for least control

(please write one number on each line):

The individual landowner
Water District
State of California
Federal Government

2. Please rank which of these groups you believe should have the most control over water use on your property. Use 1 for most control and 4 for least control

(please write one number on each line):

The individual landowner
Water District
State of California
Federal Government

Please add any additional comments your would like to make below: 
3. Please tell us how much you agree or disagree with the following statements (please circle one number for each, ranging from 1 for "strongly disagree" to 5 for "strongly agree." Or, you may circle DK for "don't know"):

\begin{tabular}{|c|c|c|c|c|c|c|}
\hline $\begin{array}{l}\text { Circle one number for } \\
\text { each line }\end{array}$ & $\begin{array}{l}\text { Strongly } \\
\text { disagree }\end{array}$ & Disagree & $\begin{array}{l}\text { Neither } \\
\text { agree or } \\
\text { disagree }\end{array}$ & Agree & $\begin{array}{l}\text { Strongly } \\
\text { agree }\end{array}$ & $\begin{array}{l}\text { Don't } \\
\text { know }\end{array}$ \\
\hline $\begin{array}{l}\text { I have plenty of water for } \\
\text { my property. }\end{array}$ & 1 & 2 & 3 & 4 & 5 & DK \\
\hline $\begin{array}{l}\text { Drought can have a big } \\
\text { impact on my ability to } \\
\text { make a living. }\end{array}$ & 1 & 2 & 3 & 4 & 5 & DK \\
\hline $\begin{array}{l}\text { Having less water would } \\
\text { reduce my ability to use } \\
\text { my property. }\end{array}$ & 1 & 2 & 3 & 4 & 5 & DK \\
\hline $\begin{array}{l}\text { I can easily adapt to a } \\
\text { water shortage. }\end{array}$ & 1 & 2 & 3 & 4 & 5 & DK \\
\hline $\begin{array}{l}\text { In general, too much } \\
\text { water is wasted by } \\
\text { users. }\end{array}$ & 1 & 2 & 3 & 4 & 5 & DK \\
\hline $\begin{array}{l}\text { Agriculture competes } \\
\text { with growing housing } \\
\text { developments for water. }\end{array}$ & 1 & 2 & 3 & 4 & 5 & DK \\
\hline $\begin{array}{l}\text { I am concerned about } \\
\text { possible future water } \\
\text { shortages }\end{array}$ & 1 & 2 & 3 & 4 & 5 & DK \\
\hline $\begin{array}{l}\text { Buying water from a } \\
\text { water district is costly. }\end{array}$ & 1 & 2 & 3 & 4 & 5 & DK \\
\hline $\begin{array}{l}\text { It is difficult to get new } \\
\text { or added water from a } \\
\text { water district. }\end{array}$ & 1 & 2 & 3 & 4 & 5 & DK \\
\hline $\begin{array}{l}\text { The local water district is } \\
\text { more supportive of } \\
\text { residential water use } \\
\text { than agricultural water } \\
\text { use. }\end{array}$ & 1 & 2 & 3 & 4 & 5 & DK \\
\hline
\end{tabular}


4. Please tell us how important or unimportant each of the following is to you in your water use decisions: (please circle one number for each, scoring them from 1, "not important at all," to 4, "very important").

\begin{tabular}{|c|c|c|c|c|}
\hline $\begin{array}{l}\text { Circle one number for } \\
\text { each line }\end{array}$ & $\begin{array}{l}\text { Not at all } \\
\text { Important }\end{array}$ & $\begin{array}{l}\text { Not very } \\
\text { Important }\end{array}$ & Important & $\begin{array}{c}\text { Very } \\
\text { important }\end{array}$ \\
\hline West Nile Virus & 1 & 2 & 3 & 4 \\
\hline Mosquitoes & 1 & 2 & 3 & 4 \\
\hline $\begin{array}{l}\text { Maintaining district water } \\
\text { allocation }\end{array}$ & 1 & 2 & 3 & 4 \\
\hline Water price & 1 & 2 & 3 & 4 \\
\hline Livestock prices & 1 & 2 & 3 & 4 \\
\hline Crop prices & 1 & 2 & 3 & 4 \\
\hline $\begin{array}{l}\text { Maintaining or increasing } \\
\text { property values }\end{array}$ & 1 & 2 & 3 & 4 \\
\hline $\begin{array}{l}\text { Cost of labor for irrigation } \\
\text { or water system }\end{array}$ & 1 & 2 & 3 & 4 \\
\hline Enjoyment of my property & 1 & 2 & 3 & 4 \\
\hline Saving water & 1 & 2 & 3 & 4 \\
\hline Landscaping & 1 & 2 & 3 & 4 \\
\hline Wildfire danger & 1 & 2 & 3 & 4 \\
\hline Other: & 1 & 2 & 3 & 4 \\
\hline Other: & 1 & 2 & 3 & 4 \\
\hline
\end{tabular}

Please add any comments below if you would like: 
5. For each water use that applies to you, please tell us where you get the water that you use ( please check all that apply-you may check more than one source for each use. Or, you may check "does not apply"):

\begin{tabular}{|c|c|c|c|c|c|}
\hline $\begin{array}{l}\text { I use water... } \\
\text { ( }\left(\begin{array}{c}\text { please check all that } \\
\text { apply for each line) }\end{array}\right.\end{array}$ & $\begin{array}{c}\text { From } \\
\text { water } \\
\text { district/ } \\
\text { canal }\end{array}$ & From well & $\begin{array}{l}\text { From } \\
\text { irrigation } \\
\text { runoff, } \\
\text { recycled } \\
\text { tailwater } \\
\text { etc. }\end{array}$ & $\begin{array}{c}\text { Creek, } \\
\text { spring, } \\
\text { other } \\
\text { natural } \\
\text { water } \\
\text { source or } \\
\text { diversion }\end{array}$ & $\begin{array}{c}\text { Does } \\
\text { not } \\
\text { apply }\end{array}$ \\
\hline \multicolumn{6}{|l|}{ for household use } \\
\hline \multicolumn{6}{|l|}{$\begin{array}{l}\text { to water a home garden } \\
\text { or orchard }\end{array}$} \\
\hline \multicolumn{6}{|l|}{$\begin{array}{l}\text { to irrigate a commercial } \\
\text { crop or orchard }\end{array}$} \\
\hline \multicolumn{6}{|l|}{$\begin{array}{l}\text { to reduce fire hazard by } \\
\text { creating a green space }\end{array}$} \\
\hline \multicolumn{6}{|l|}{ to water livestock } \\
\hline \multicolumn{6}{|l|}{$\begin{array}{l}\text { to irrigate pasture for } \\
\text { livestock }\end{array}$} \\
\hline \multicolumn{6}{|l|}{$\begin{array}{l}\text { to create wildlife habitat } \\
\text { or provide water for } \\
\text { wildlife }\end{array}$} \\
\hline \multicolumn{6}{|l|}{$\begin{array}{l}\text { to create or maintain a } \\
\text { pond }\end{array}$} \\
\hline \multicolumn{6}{|l|}{$\begin{array}{l}\text { to meet legal } \\
\text { requirements for fire } \\
\text { protection }\end{array}$} \\
\hline \multicolumn{6}{|l|}{ for other reason: } \\
\hline for other reason: & & & & & \\
\hline
\end{tabular}

Please tell us if you get water from any other sources here: 
6. Do you have a pond on your property? ( $\square$ please check yes or no below)

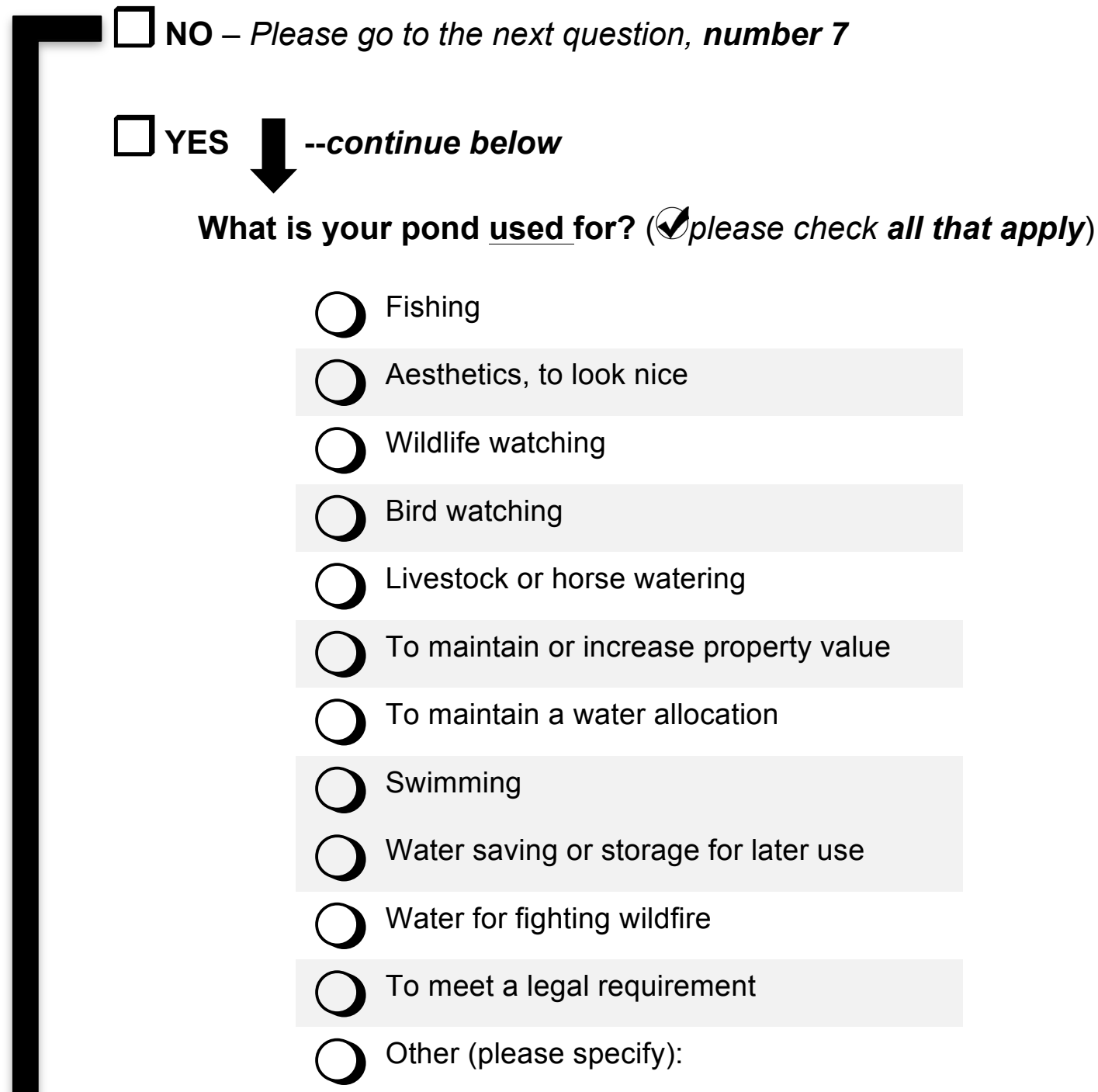

7. Do you have the following on your property? ( please check all that apply)
Irrigation canal or irrigation ditch
Irrigation pipes 
8. Approximately how many of the following types of water dependent areas do you have on your property?

( $\square$ please check one answer for each line)

\begin{tabular}{|c|c|c|c|c|}
\hline $\begin{array}{l}\text { I have the following water dependent } \\
\text { areas ( } \square \text { check one for each): }\end{array}$ & $\mathbf{0}$ & $\begin{array}{c}1-10 \\
\text { areas }\end{array}$ & $\begin{array}{l}\text { More } \\
\text { than ten } \\
\text { areas }\end{array}$ & $\begin{array}{l}\text { Don't } \\
\text { know }\end{array}$ \\
\hline Irrigated pasture (check one) & & & & DK \\
\hline Springs (check one) & & & & DK \\
\hline Ponds (check one) & & & & DK \\
\hline $\begin{array}{l}\text { Shallow wet areas, like from pasture } \\
\text { runoff, a canal leak, or a spring (see } \\
\text { back cover) (check one) }\end{array}$ & & & & DK \\
\hline Irrigated crops (check one) & & & & DK \\
\hline Water trough (check one) & & & & DK \\
\hline Other & & & & DK \\
\hline
\end{tabular}

9. Do you have irrigated pasture? ( $\square$ please check yes or no below)

NO -Please go to question 10 on the opposite page

YES - Continue below: How often do you typically irrigate an individual pasture in the hot part of the summer?

( $\square$ please check only one answer)

$\square$ Daily

$\square$ Twice a week

$\square$ Once a week

$\square$ Every other week

$\square$ Once a month

No typical amount-I water as needed 
10. In the past $\mathbf{5}$ years, how many times have you or your water district carried out the following water, yard, or pasture management actions on your property? (অcheck one frequency for each and indicate if the water district carried out any part of the actions)

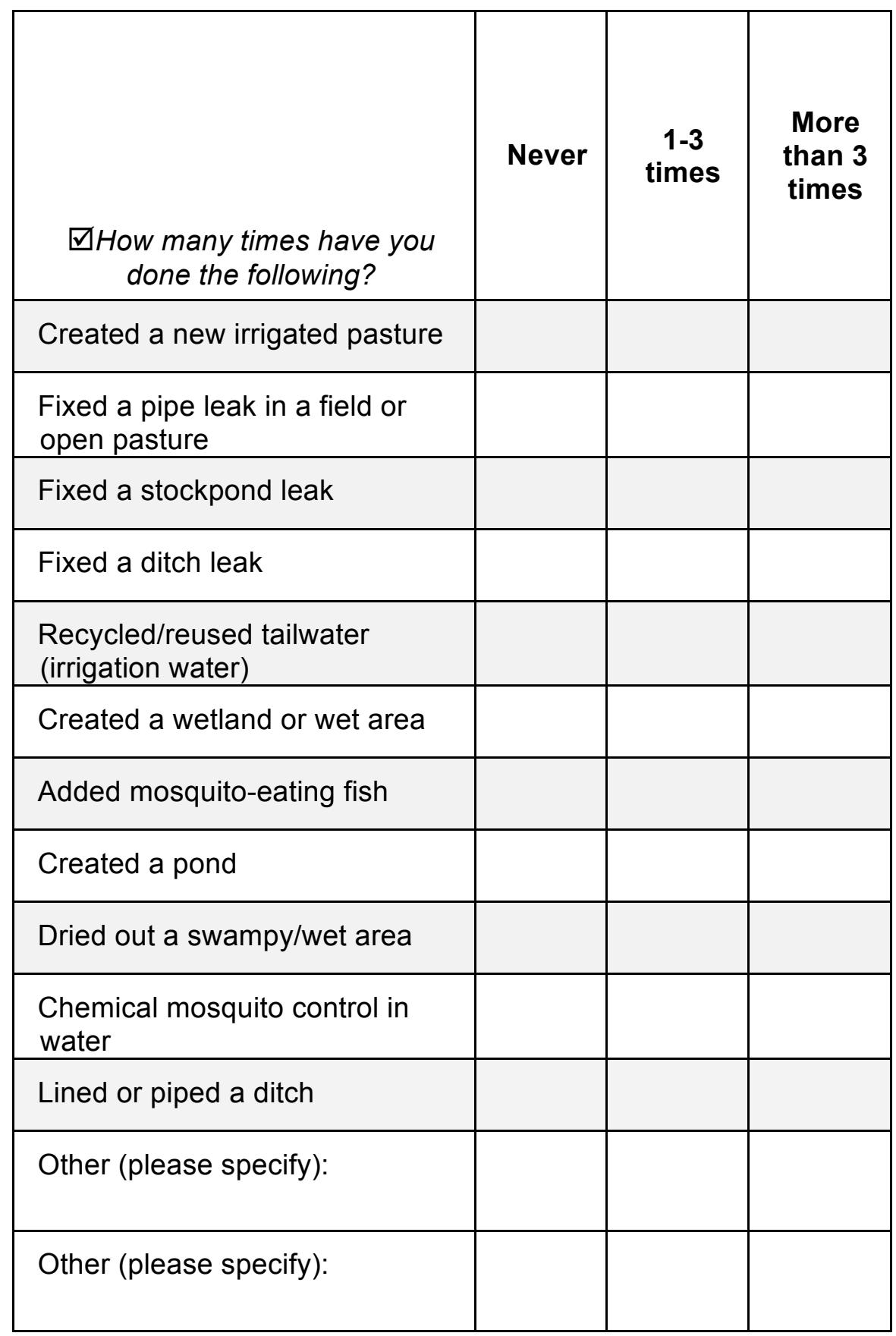

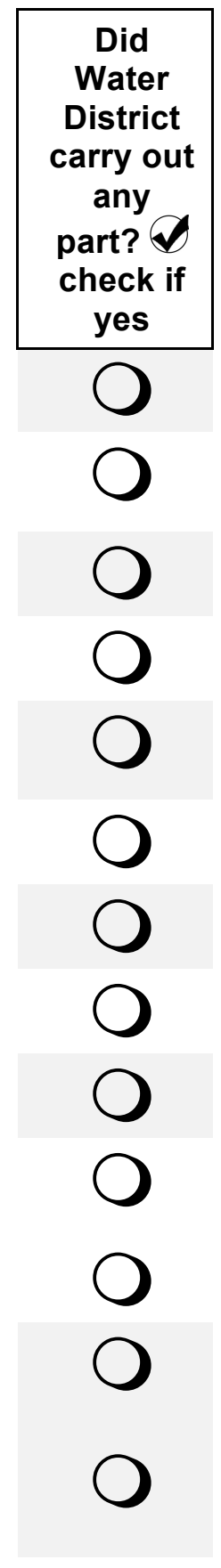


11. Have you used untreated water, or irrigation water, from a water district within the last 2 years?

( $\square$ please check yes or no below)

$\square$ NO -if you did not use irrigation or untreated water, go to question 19, page 15

YES - please continue

11b. Which water district did you get water from?

(Dplease check all that apply)

$\bigcirc$ Nevada Irrigation District (NID)

Brophy Water District

Browns Valley Irrigation District (BVID)

Coruda Water District

Dry Creek Mutual Water Company

Hallwood Irrigation District

Ramirez Water District

South Yuba Water District

Wheatland Water District

North Yuba Water District

South Feather Water District

Other (please write in) 
[note: if you do not use water district irrigation or untreated water, skip to question 19 on pg. 15]

12. It is important for us to understand the cost of water to landowners. Approximately how much do you spend each year for untreated or irrigation water from each water district for your property?

(please fill in)

\begin{tabular}{|l|l|}
\hline Water District & $\begin{array}{c}\text { Annual Total } \\
\text { Expense }\end{array}$ \\
\hline & \\
\hline & \\
\hline & \\
\hline & \\
\hline & \\
\hline
\end{tabular}

If you like, please make any comments here: 
13. During the drought in 2008 , many water districts cut the amount of untreated or irrigation water they provided, and others asked water users to voluntarily reduce use. Was your water supply reduced, or did you voluntarily reduce water use for this property?

(অplease check one)

$\square$ Did not own the property or buy water in 2008-

please go to question 16 next page

$\square$ NO --water supply not reduced and I did not reduce use -

please go to question 16 next page

$\square$ YES --water supply reduced or I voluntarily reduced use-

7 please continue below.

14. About how much was your water use reduced by, in percent, in 2008 (please fill in your estimate): $\%$

15. How did you deal with reduced water supply or voluntarily reduced use in 2008? (Please check all that apply):

I did not need to do anything.

Stopped or reduced purchasing water

Repaired leaks in ditches, pipes, dams, and/or ponds

Recycled and/or reduced tailwater, irrigation, or pond runoff

Sold some of my land

Stopped or reduced growing crops or gardening

Stopped or used less water to irrigate pasture(s)

Reduce area of irrigated pasture

Sold livestock or reduced stocking rate on property

Found grazing land somewhere else

Substituted well water or used other water sources from my land

Purchased water from outside sources

Changed to a different land use (please explain):

Other (please explain): 
[note: if you do not use water district irrigation or untreated water, skip to question 19 on pg. 15]

16A. Please tell us what you would do if the price of untreated or irrigation water went up by $20 \%$ in 2014 (for example from $\$ 10.00$ to $\$ 12.00$ per unit of water, or a fifth)?

(Please check all that apply):

$\bigcirc$ I would not have to do anything

Stop or reduce purchasing water

Repair leaks in ditches, pipes, dams, and/or ponds

Recycle and/or reduce tailwater, irrigation, or pond runoff

Sell some or all of the land

Stop or reduce growing crops or gardening

Stop or use less water to irrigate pasture(s)

$\bigcirc$ Reduce area of irrigated pasture

$\bigcirc$ Sell livestock or reduce stocking rate

Find other grazing land

Purchase water from outside (non-district) sources

Substitute well water or use other water sources on your land

Change to a different land use (please explain):

Other (please explain):

If you like, please add any comments about how you would adjust to a higher water price here or on the next page: 
17. What would be the maximum $\%$ increase in water price you could pay for untreated or irrigation water before you would have to change the way you use water in the management of your property?

(please fill in below)

I could afford a _ $\%$ increase in water price before I would have to change the way I use water to manage the property.

18. Which water use would you change first if water prices exceeded your maximum price above?

--Please explain: 
19A. Please tell us what you would do if your water availability from all nonresidential sources was cut by a fifth $(20 \%)$ this year:

(Dlease check all that apply)

\author{
I would not have to do anything \\ Repair leaks in ditches, pipes, dams, and/or ponds \\ Recycle and/or reduce tailwater, irrigation, or pond runoff \\ Sell some or all of the land \\ Stop or reduce growing crops or gardening \\ Stop or use less water to irrigate pasture(s) \\ $\bigcirc$ Reduce area of irrigated pasture \\ Sell livestock or reduce stocking rate \\ Find other grazing land \\ Purchase from outside (non-district) sources \\ $\bigcirc$ Change to a different land use (please explain):
}

Other (please explain):

If you like, please add any comments here: 
The following questions are about wetlands like those pictured below, and in color on the back cover. These exist because of the unique way that water is transported in Yuba, Butte, and Nevada Counties, and we would like to understand how they are managed.

Please examine the photograph below (also found in color on the back of this booklet). This is what we call a "shallow hillside wetland" (Wetland Type A). The water is, at most, only a few inches deep and it is on a slope. Please answer the following questions for these kinds of wetlands:

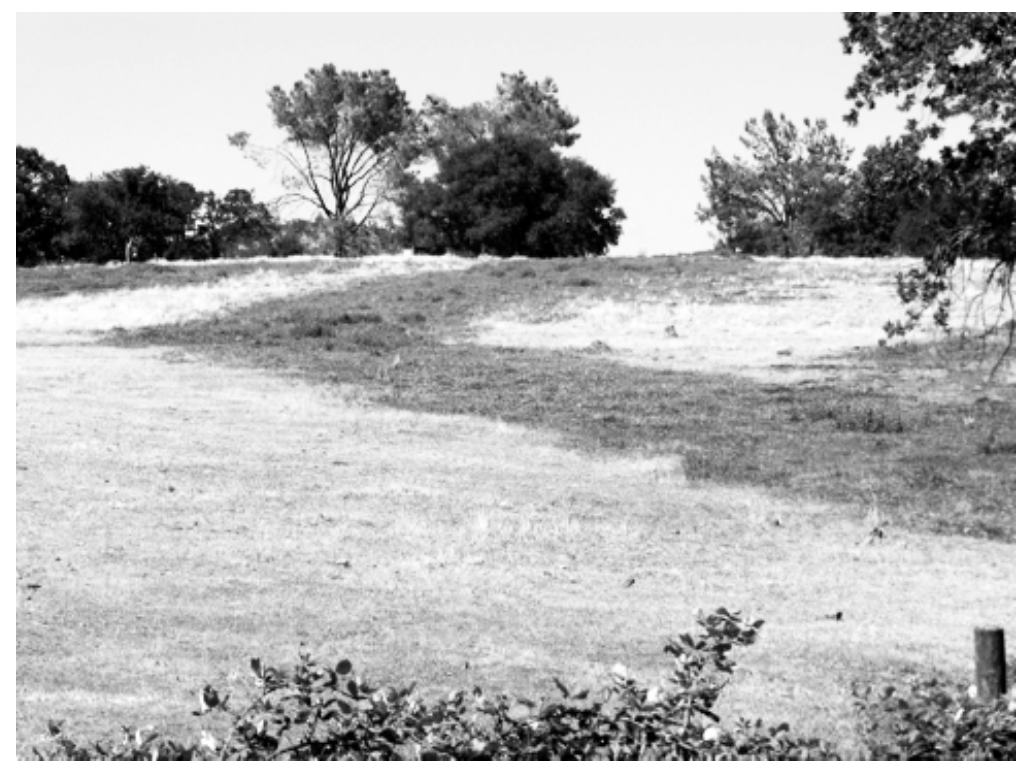

20. What do you most often do when you find shallow hillside wetland areas that are created by springs, or leaks in ditches, stockponds, or pipes?

( $\square$ please check one)

$\square$ I don't have shallow hillside wetlands

$\square$ Leave them alone

$\square$ Drain them

$\square$ Fix the leak or channel the runoff

$\square$ Protect from grazing 
21. When you dry or drain shallow hillside wetlands on your property, why do you do that? ( $\square$ please check all that apply)

I do not drain or dry up shallow hillside wetlands

To reduce mosquitos

Concerns about West Nile Virus

I don't like wet areas like this on my property

To improve forage quality

To save water

To better use my property

To save money

For another reason (please explain):

22. When you leave shallow hillside wetlands on your property alone, why do you do that? ( $D$ please check all that apply)

I do not leave shallow hillside wetlands alone

For livestock forage

It's too expensive to fix them

For wildlife habitat

For bird watching

I like how they look

I've never thought about it

They don't bother me

Would like to drain them, but need advice or assistance

For another reason (please explain): 
Please look at the photograph below (also found in color on the back of this booklet). These are also only a few inches deep at most, and some of the water is moving. We call these "shallow level wetlands" (Wetland Type B). Please answer the following questions for these kinds of wetlands:

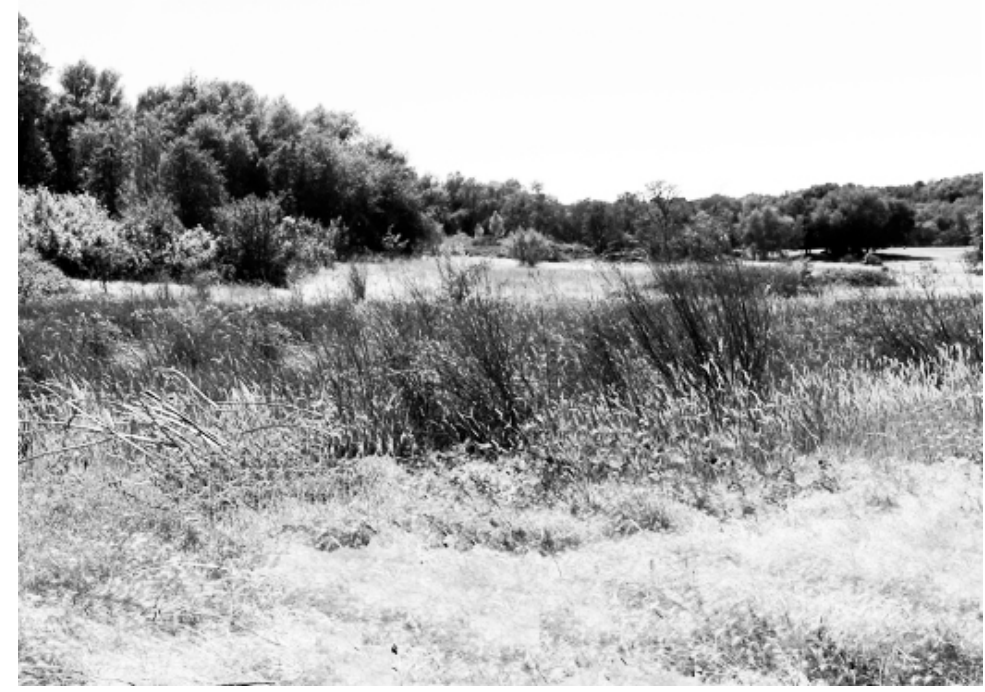

24. What do you most often do when you find shallow wetlands in flat or low lying areas that are created by springs, or runoff or leaks in ditches, stockponds, or pipes?

( $\square$ please check one)
$\square$
I don't have shallow level wetlands
$\square$
Leave them alone
$\square$ Drain them
$\square$ Fix the leak or channel the runoff
$\square$ Protect from grazing

Please make any comments here if you like: 
25. If you drain or dry up shallow level wetlands on your property, why do you do that? ( please check all that apply)
I do not drain or dry up shallow level wetlands
To reduce mosquitos
Concerns about West Nile Virus
I don't like wet areas like this on my property
To improve forage quality
To save water
To make better use of my property
To save money
For another reason (please explain):

26. When you leave shallow level wetlands on your property alone, why do you do that? ( please check all that apply)
I do not leave shallow level wetlands alone
For livestock forage
It's too expensive to fix them
For wildlife habitat
For bird watching
I like how they look
I've never thought about it
They don't bother me
Would like to drain them, but need advice or assistance
For another reason (please explain): 
27. Please indicate how much you agree or disagree with the following statements about small shallow wetlands and their use by livestock, mosquitos, and wildlife (circle one number for each, with 1 for "strongly disagree" and 5 for "strongly agree").

\begin{tabular}{|c|c|c|c|c|c|c|}
\hline $\begin{array}{l}\text { (please circle one } \\
\text { number for each line) }\end{array}$ & $\begin{array}{l}\text { Strongly } \\
\text { disagree }\end{array}$ & Disagree & $\begin{array}{l}\text { Neither } \\
\text { agree or } \\
\text { disagree }\end{array}$ & Agree & $\begin{array}{l}\text { Strongly } \\
\text { agree }\end{array}$ & $\begin{array}{l}\text { Don't } \\
\text { know }\end{array}$ \\
\hline $\begin{array}{l}\text { Small wetlands that are } \\
\text { not too boggy provide } \\
\text { useful green summer } \\
\text { forage }\end{array}$ & 1 & 2 & 3 & 4 & 5 & DK \\
\hline $\begin{array}{l}\text { I am concerned that } \\
\text { wetlands might reduce } \\
\text { a landowner's ability to } \\
\text { use the land }\end{array}$ & 1 & 2 & 3 & 4 & 5 & DK \\
\hline $\begin{array}{l}\text { I am concerned that } \\
\text { wetlands might attract } \\
\text { mosquitos }\end{array}$ & 1 & 2 & 3 & 4 & 5 & DK \\
\hline $\begin{array}{l}\text { I am concerned about } \\
\text { West Nile Virus from } \\
\text { hillside wetlands on or } \\
\text { near my property }\end{array}$ & 1 & 2 & 3 & 4 & 5 & DK \\
\hline $\begin{array}{l}\text { Wetlands improve the } \\
\text { look of a property }\end{array}$ & 1 & 2 & 3 & 4 & 5 & DK \\
\hline $\begin{array}{l}\text { A hillside wetland } \\
\text { reduces the quality of } \\
\text { grazing land }\end{array}$ & 1 & 2 & 3 & 4 & 5 & DK \\
\hline $\begin{array}{l}\text { I do not like to see } \\
\text { boggy spots on a } \\
\text { property }\end{array}$ & 1 & 2 & 3 & 4 & 5 & DK \\
\hline $\begin{array}{l}\text { I like wetlands because } \\
\text { they attract wildlife }\end{array}$ & 1 & 2 & 3 & 4 & 5 & DK \\
\hline $\begin{array}{l}\text { I am concerned that } \\
\text { these wetlands are a } \\
\text { waste of water }\end{array}$ & 1 & 2 & 3 & 4 & 5 & DK \\
\hline
\end{tabular}


28. If private funds or government incentives (like NRCS, RCD, local Water District) were available to landowners to enhance habitat for birds using wetlands like those on the back cover, how much would you want to be paid to create a small, shallow wetland (like A or B) on your property? Assume that the wetland could be used for livestock grazing except during nesting in springtime

( please check all that apply).

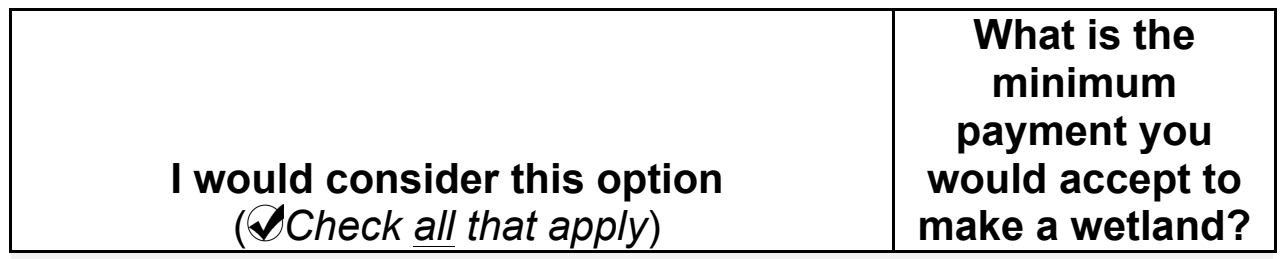

I would do it if I received a one-time payment as compensation for creating a wetland from a group I trust and respect.

$\$$ only one year

I would do it if I received an annual payment for maintaining the wetland from a group I trust and respect.

$\$$ year for every several years

I would do it if I received a one-time payment for permanently protecting an existing wetland from a group I $\$$ for trust and respect. only one year

I would do it for free if I thought it benefited birds and wildlife.

I would do it in exchange for free water to create it.

I would do it if my livestock could graze on it in the summer.

I would probably never create a wetland.

Can you give us any examples of groups that you might accept funding from for maintaining or creating small wet areas? 
29. If you have any ideas about what kinds of incentives would encourage a landowner to create small wetlands, please let us know here:

30. What might stop landowners from creating small wetlands on their properties?

31. Have you had any past personal experiences with West Nile Virus? For example, do you know anyone who has contracted West Nile Virus or had a horse contract the disease?

( $\square$ please check one)

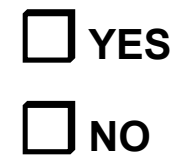

If yes, please explain:

32. Do you vaccinate horses or other animals for West Nile Virus? ( $\square$ please check one)

YES

NO 
33. Please let us know if you participate in any of the following land stewardship programs:

(please check one response for each):

\begin{tabular}{|l|l|l|l|l|}
\hline $\begin{array}{l}\text { Do you participate? (please check one } \\
\text { response for each line) }\end{array}$ & YES & NO & Not Sure & $\begin{array}{c}\text { Not } \\
\text { familiar } \\
\text { with } \\
\text { program }\end{array}$ \\
\hline Enrolled in the Williamson Act? & & & & \\
\hline Enrolled as Timber Production Zone? & & & & \\
\hline $\begin{array}{l}\text { Have you written a Rangeland Water Quality } \\
\text { Management Plan? }\end{array}$ & & & & \\
\hline $\begin{array}{l}\text { Do you have a Forest Certification? } \\
\text { Have a mitigation or conservation easement } \\
\text { on your land? }\end{array}$ & & & & \\
\hline $\begin{array}{l}\text { Have you participated in the emergency feed } \\
\text { or drought relief program? }\end{array}$ & & & & \\
\hline $\begin{array}{l}\text { Participate in mitigation banking? } \\
\text { Participate in CDFW's (CDFG) "Private } \\
\text { Lands Management" program (AB 580)? }\end{array}$ & & & & \\
\hline $\begin{array}{l}\text { Participate in the new USFWS partners } \\
\text { program? }\end{array}$ & & & & \\
\hline $\begin{array}{l}\text { Participated in a Wildlife Habitat } \\
\text { Improvement Project (WHIP)? }\end{array}$ & & & & \\
\hline $\begin{array}{l}\text { Participated in an Environmental Quality } \\
\text { Incentives Project (EQIP)? }\end{array}$ & & & & \\
\hline $\begin{array}{l}\text { Participate in Resource Conservation District } \\
\text { programs (RCD)? }\end{array}$ & & & & \\
\hline $\begin{array}{l}\text { Pny other programs important to you? } \\
\text { Plecify: }\end{array}$ & & & & \\
\hline
\end{tabular}


34. How important or unimportant to you are any of the following reasons for owning your land? (please circle one number for each, scoring them from 1, "not important at all," to 4, "very important").

\begin{tabular}{|l|c|c|c|c|}
\hline $\begin{array}{l}\text { Reasons for owning land } \\
\text { (please circle one number for } \\
\text { each line): }\end{array}$ & $\begin{array}{c}\text { Not at all } \\
\text { Important }\end{array}$ & $\begin{array}{c}\text { Not very } \\
\text { Important }\end{array}$ & Important & Very important \\
\hline $\begin{array}{c}\text { My land is a source of } \\
\text { income }\end{array}$ & 1 & 2 & 3 & 4 \\
\hline $\begin{array}{c}\text { My land is a financial } \\
\text { investment }\end{array}$ & 1 & 2 & 3 & 4 \\
\hline $\begin{array}{l}\text { I like to live near natural } \\
\text { beauty }\end{array}$ & 1 & 2 & 3 & 4 \\
\hline $\begin{array}{c}\text { My land allows me to protect } \\
\text { the environment }\end{array}$ & 1 & 2 & 3 & 4 \\
\hline $\begin{array}{l}\text { I want to pass this land to my } \\
\text { heirs }\end{array}$ & 1 & 2 & 3 & 4 \\
\hline $\begin{array}{l}\text { I want to escape or stay } \\
\text { away from the city }\end{array}$ & 1 & 2 & 3 & 4 \\
\hline $\begin{array}{l}\text { I like to live in a smaller } \\
\text { community }\end{array}$ & 1 & 2 & 3 & 4 \\
\hline $\begin{array}{l}\text { I am closer to friends and } \\
\text { family here }\end{array}$ & 1 & 2 & 3 & 4 \\
\hline For recreation & 1 & 2 & 3 & 4 \\
\hline $\begin{array}{l}\text { I enjoy seeing wildlife and/or } \\
\text { birds }\end{array}$ & 1 & 2 & 3 & 4 \\
\hline $\begin{array}{l}\text { Living on this land is a family } \\
\text { business }\end{array}$ & 1 & 2 & 3 & 4 \\
\hline $\begin{array}{l}\text { I want to restore and manage } \\
\text { this land }\end{array}$ & 1 & 2 & 3 & 4 \\
\hline \begin{tabular}{l} 
I enjoy improving this land \\
\hline
\end{tabular} & 1 & 2 & 2 & 3 \\
\hline
\end{tabular}




\begin{tabular}{|c|c|c|c|c|}
\hline $\begin{array}{l}\text { Reasons for owning land } \\
\text { (please circle one number } \\
\text { for each line): }\end{array}$ & $\begin{array}{l}\text { Not at all } \\
\text { important }\end{array}$ & $\begin{array}{l}\text { Not very } \\
\text { important }\end{array}$ & Important & $\begin{array}{c}\text { Very } \\
\text { Important }\end{array}$ \\
\hline I enjoy hunting or fishing & 1 & 2 & 3 & 4 \\
\hline $\begin{array}{l}\text { This is a healthy place to } \\
\text { live }\end{array}$ & 1 & 2 & 3 & 4 \\
\hline $\begin{array}{l}\text { To grow some of my own } \\
\text { food }\end{array}$ & 1 & 2 & 3 & 4 \\
\hline To raise cattle or sheep & 1 & 2 & 3 & 4 \\
\hline $\begin{array}{l}\text { To raise horses, ponies, } \\
\text { donkeys, or mules }\end{array}$ & 1 & 2 & 3 & 4 \\
\hline $\begin{array}{l}\text { To contribute to the local } \\
\text { economy }\end{array}$ & 1 & 2 & 3 & 4 \\
\hline To preserve open space & 1 & 2 & 3 & 4 \\
\hline $\begin{array}{l}\text { To develop the land for } \\
\text { future residential use }\end{array}$ & 1 & 2 & 3 & 4 \\
\hline For vacations & 1 & 2 & 3 & 4 \\
\hline I was born here or near here & 1 & 2 & 3 & 4 \\
\hline $\begin{array}{l}\text { A good place to raise my } \\
\text { children }\end{array}$ & 1 & 2 & 3 & 4 \\
\hline Other (please specify): & 1 & 2 & 3 & 4 \\
\hline Other (please specify): & 1 & 2 & 3 & 4 \\
\hline
\end{tabular}

If you like, please comment about any other reasons you own your land: 
35. Is there a paid manager for this land?

( $\square$ please check one)

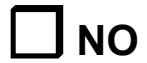

$\square$ YES

36. Is this land leased out for grazing or farming?

( $\square$ please check one)

$\square$ NO

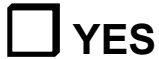

37. How long do you intend to own this land?

( $\square$ please check only one)

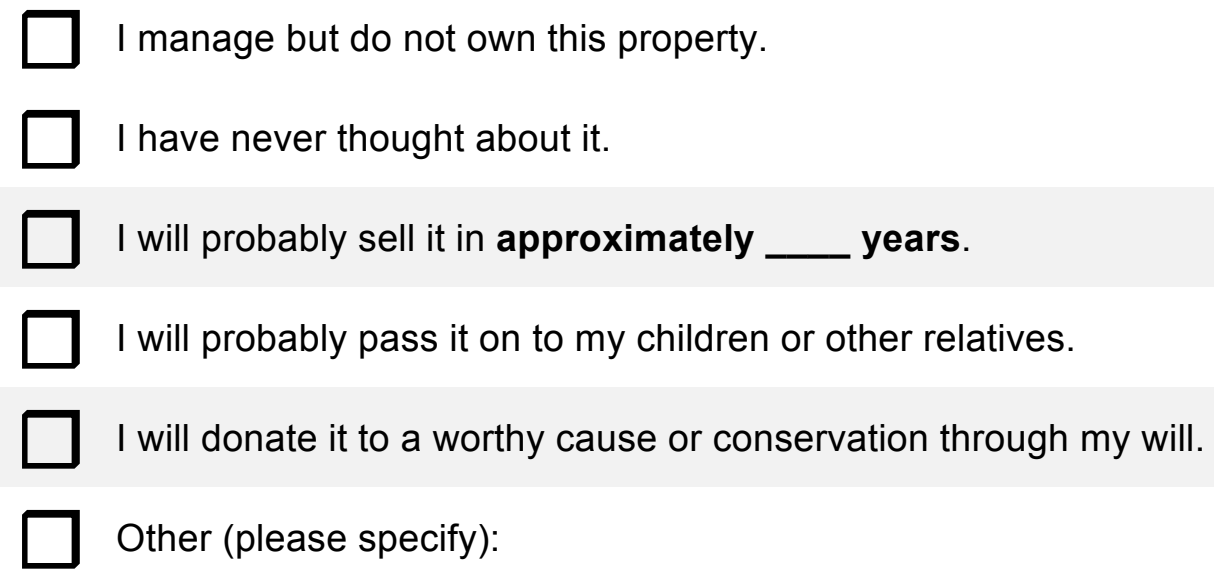

38. Please tell us approximately how many acres there are on this property: (please fill in) 
39. As of 2013, how long has the owner or the owner's family owned all or part of this land?

(please fill in)

40. How many months of the year does an owner usually live on this land? ( $\square$ please check one)

\footnotetext{
$\square$ An owner does not live on this land

$\square 3$ months or less

$\square$ 4-11 months

all year (12 months)
} 
41. In the last five years did you discuss or get advice about land management from the following organizations?

( $D$ please check all that apply)

UC Cooperative Extension (UCCE County Farm Advisor or Specialist)

UC Black Rail Inventory

Professional consultant

Natural Resource Conservation Service (NRCS)

California Department of Forestry and Fire Protection (CAL FIRE)

U.S. Forest Service

U.S. Fish and Wildlife Service

California Department of Fish and Wildlife (formerly CDFG_Fish and Game)

Land conservation organization or land trust (ex. The Nature Conservancy, Pacific Forest Trust, Placer Land Trust)

Books or magazines

Internet

Television or Radio

Resource Conservation District

Industry Association (ex. Cattlemen's, Woolgrowers, Farm Bureau)

Professional Organization (ex.Society of American Foresters, Society for Range Management, Horticultural Society)

Private Company (please specify):

Other (please explain): 
Finally, please tell us a few things about yourself. This information will only be used for statistical purposes. Your answers will not be connected with your name.

42. How old are you? years

43. What is your gender:

( $\square$ please check one)

$\square$ Male

$\square$ Female

44. What is your approximate household annual income before taxes?

( $\square$ please check one)

$\square \quad$ Up to $\$ 29,999$

$\square \$ 100,000$ to 149,999

$\square \$ 30,000$ to 59,999

$\square \$ 150,000$ to 199,999

$\square \$ 60,000$ to 99,999

$\$ 200,000$ or more

45. Approximately what percentage of your gross annual income comes from this land?

(Place a mark at the closest point on line below.)

0------20-------30------40------50 $-100 \%$

46. What is your marital status?

( $\square$ please check one)

Married or living with partner

Single 
47. Which category or categories fit your career or employment status?

( $\checkmark$ please check all that apply).
Farmer
Rancher
Home-maker
Student
Self-employed
Retired
Blue collar/skilled trade
Unemployed
Professional
Part-time
Other (please explain):

48. What is your highest level of education?

( $\square$ please check one)
$\square$
Some school
$\square$ High school diploma
$\square$ Some college
$\square$ Bachelor's degree or equivalent
$\square$ Master's degree
$\square$ Ph.D., M.D., J.D., or equivalent

49. Do you consider you or your family to be of any particular ethnic or ancestral background?

If so, please tell us what it is (German-American, Hispanic, etc.): 
50. Please add any comments or ideas you might have about water management in the foothills, small wetlands, or wildlife in the space below.

Thank you for filling out this survey. Your opinions and suggestions are very important to us. 


\section{TWO KINDS OF SMALL WETLANDS IN OUR AREA}

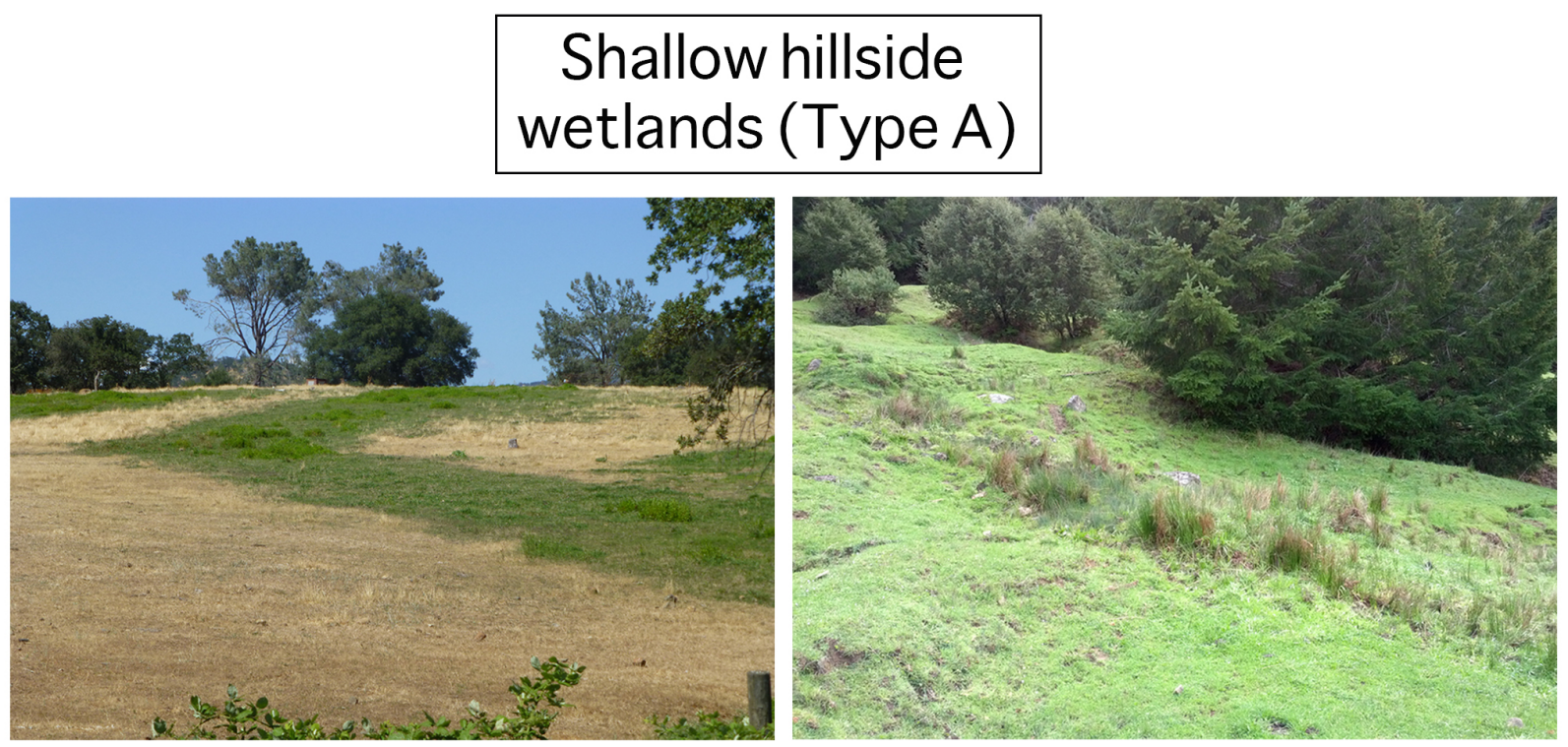

\section{Shallow level wetlands (Type B)}
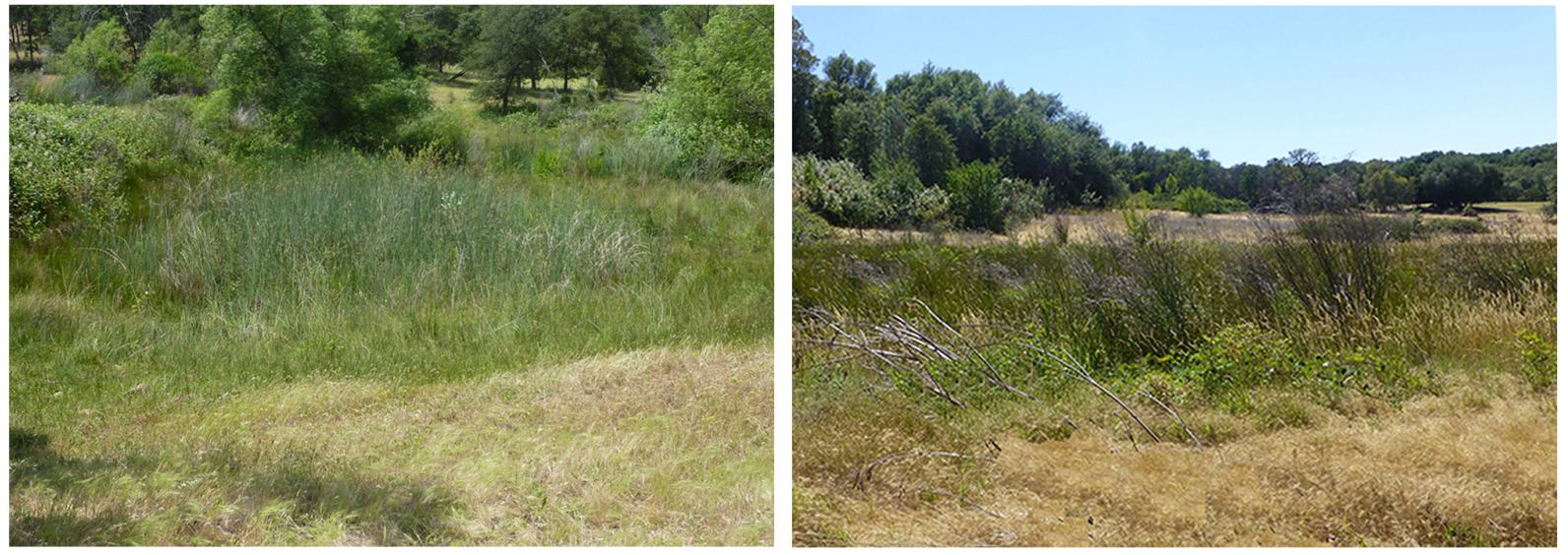